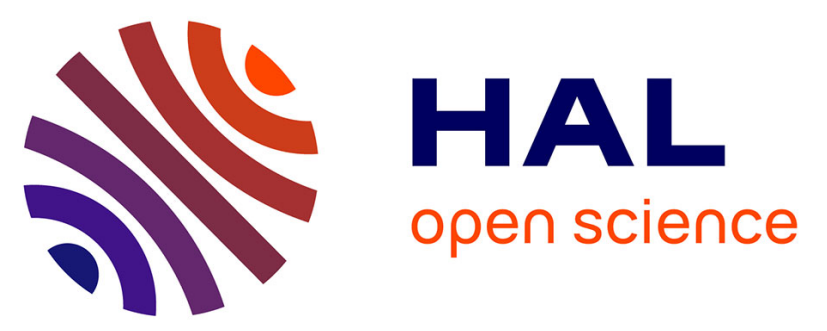

\title{
Medium-term effects of Ag supplied directly or via sewage sludge to an agricultural soil on Eisenia fetida earthworm and soil microbial communities
}

Pauline Courtois, Agnieszka Rorat, Sébastien Lemiere, Remy Guyoneaud, Eléonore Attard, Manon Longepierre, François Rigal, Clément Levard, Perrine

Chaurand, Anna Grosser, et al.

\section{To cite this version:}

Pauline Courtois, Agnieszka Rorat, Sébastien Lemiere, Remy Guyoneaud, Eléonore Attard, et al.. Medium-term effects of $\mathrm{Ag}$ supplied directly or via sewage sludge to an agricultural soil on Eisenia fetida earthworm and soil microbial communities. Chemosphere, 2021, 269, pp.128761. 10.1016/j.chemosphere.2020.128761 . hal-03149939

\section{HAL Id: hal-03149939 \\ https://hal.science/hal-03149939}

Submitted on 8 Mar 2021

HAL is a multi-disciplinary open access archive for the deposit and dissemination of scientific research documents, whether they are published or not. The documents may come from teaching and research institutions in France or abroad, or from public or private research centers.
L'archive ouverte pluridisciplinaire HAL, est destinée au dépôt et à la diffusion de documents scientifiques de niveau recherche, publiés ou non, émanant des établissements d'enseignement et de recherche français ou étrangers, des laboratoires publics ou privés.

\section{(1) (1) $\$$}

Distributed under a Creative Commons Attribution - NonCommercial - NoDerivatives 44.0 
1 Medium-term effects of Ag is supplied directly or via sewage sludge to an agricultural soil on Eisenia fetida earthworm and soil microbial communities.

4 Pauline Courtois $^{1^{*}}$, Agnieszka Rorat ${ }^{1}$, Sébastien Lemiere ${ }^{1}$, Rémy Guyoneaud ${ }^{2}$, Eléonore 5 Attard $^{2}$, Manon Longepierre ${ }^{2}$, François Rigal ${ }^{3}$, Clément Levard ${ }^{4}$, Perrine Chaurand ${ }^{4}$, Anna

6 Grosser $^{5}$, Anna Grobelak ${ }^{5}$, Malgorzata Kacprzak ${ }^{5}$, Christine Lors ${ }^{1}$, Agnès Richaume ${ }^{6}$ and $7 \quad$ Franck Vandenbulcke ${ }^{1}$

${ }^{1}$ Univ. Lille, IMT Lille Douai, Univ. Artois, Yncrea Hauts-de-France, ULR4515 - LGCgE,

Laboratoire de Génie Civil et géo-Environnement, F-59000 Lille, France

2 Université de Pau et des Pays de l'Adour, E2S UPPA, CNRS, UMR IPREM 5254,

Environmental Microbiology, 64000, Pau, France

${ }^{3}$ Azorean Biodiversity Group, Centre for Ecology, Evolution and Environmental Changes

(CE3C), Departamento de Ciências Agráriase Engenharia do Ambiente, Universidade dos

Açores, PT-9700-042 Angra do Heroísmo, Açores, Portugal

${ }^{4}$ Aix Marseille Univ, CNRS, IRD, INRAE, Coll France, CEREGE, Aix-en-Provence, France

5 Czesstochowa University of Technology, Faculty of Infrastructure and Environment,

Czestochowa, Poland

${ }^{6}$ LEM - Laboratoire d'Ecologie Microbienne - UMR 5557 - 69622 Villeurbanne, France

*Address correspondence to: Pauline Courtois

e-mail:pauline.courtois@univ-lille.fr

Université de Lille, Sciences et Technologies

Laboratoire de Génie Civil et géo-Environnement, LGCgE EA4515

Cité Scientifique, Bât. SN3 - F-59655 Villeneuve d'Ascq 


\section{Abstract}

The widespread use of silver nanoparticles (AgNPs) in consumer products that release Ag throughout their life cycle has raised potential environmental concerns. AgNPs primarily accumulate in soil through the spreading of sewage sludge (SS). In this study, the effects of direct exposure to AgNPs or indirect exposure via SS contaminated with AgNPs on the earthworm Eisenia fetida and soil microbial communities were compared, through 3 scenarios offering increasing exposure concentrations. The effects of Ag speciation were analyzed by spiking SS with AgNPs or $\mathrm{AgNO}_{3}$ before application to soil. SS treatment strongly impacted $\mathrm{Ag}$ speciation due to the formation of $\mathrm{Ag}_{2} \mathrm{~S}$ species that remained sulfided after mixing in the soil. The life traits and expression of lysenin, superoxide dismutase, cd-metallothionein genes in earthworms were not impacted by Ag after 5 weeks of exposure, but direct exposure to $\mathrm{Ag}$ without SS led to bioaccumulation of Ag, suggesting transfer in the food chain. Ag exposure led to a decrease in potential carbon respiration only when directly added to the soil. The addition of SS had a greater effect on soil microbial diversity than the form of Ag, and the formation of $\mathrm{Ag}$ sulfides in SS reduced the impact of AgNPs on E. fetida and soil microorganisms compared with direct addition.

Keywords: Silver nanoparticles, silver sulfide, ecotoxicology, earthworms, microorganisms, speciation 


\section{Introduction}

Silver nanoparticles (AgNPs) are widely used in various industries due to their unique properties (Vance et al., 2015). The use of AgNPs in common consumer products leads indirectly to environmental contamination (McGillicuddy et al., 2017). From manufacture to the end of life of nano-functionalized products, the release of silver (Ag) in wastewater is significant. Wastewater treatment plants (WWTPs) remove approximately $90 \%$ of AgNPs from influents as sewage sludge (SS) (Kaegi et al., 2011; Ma et al., 2014; Tiede et al., 2010). Treated SS is a biosolid rich in nutrients and organic matter and can be applied to agricultural soils as fertilizer according to the circular economy aims of policymakers (European commission, 2017). Currently, there are no regulatory thresholds or recommendations for the Ag content of SS used as fertilizer, and the ecotoxicity of Ag amendments to soil has not been fully characterized. Based on previous studies and gaps in the field, Courtois et al. (2019) noted that the risk associated with environmental contamination by $\mathrm{Ag}$ is poorly understand because of the complexity of the soil matrix and the chemical transformations of AgNPs.

The present study sought to link silver speciation with its impact on the earthworm Eisenia fetida, an important soil fauna test species in ecotoxicology, and on the natural microflora. Earthworms are widely studied among soil invertebrates because they play a key role in most continental ecosystems and represent an important part of the soil macrofauna. They are considered "soil engineers" (Carbonell et al., 2009) that participate in the maintenance of soil structure and fertility. In addition to enriching the soil with organic matter available for plants, earthworms contribute to soil aeration and promote water penetration by forming galleries during their movements (Bernard et al., 2010; Carbonell et al., 2009). Several studies have shown that direct exposure to Ag in soil does not affect earthworm survival when the concentration does not exceed a few tens of $\mathrm{mg} \mathrm{kg}^{-1}$ (Courtois et al., 2019). However, reproduction is more sensitive to Ag exposure (Diez-Ortiz et al., 2015; Novo et al., 2015; 
Schlich et al., 2013), and different stress markers have been observed (Gomes et al., 2015; Hayashi et al., 2013; Shoults-Wilson et al., 2010). Exposure to the same concentrations of Ag in SS appears to have reduced effects on earthworms compared with direct exposure, but only two studies have addressed this issue (Lahive et al., 2017; Velicogna et al., 2017), without verifying the speciation of Ag.

Soil microorganisms are key players in several ecosystem services. They participate in soil fertility and stability via their roles in numerous biogeochemical cycles and degradation of contaminants. Soil microorganisms also influence crop health via competition with pathogens (Vance et al., 2015). Given the biocidal action of AgNPs, their effects on microorganisms are of major concern. Several studies have reported decreases in the abundance and activities of microorganisms and changes in the diversity of microbial communities in response to direct exposure depending on the dose of AgNPs (Courtois et al., 2019; Hänsch and Emmerling, 2010; He et al., 2016; Kumar et al., 2014; Liu et al., 2017; McGee et al., 2017; Samarajeewa et al., 2017; Sillen et al., 2015). However, a much different pattern of response was observed after exposure to AgNPs supplied via SS, with no or weak effects on the microbial communities (Asadishad et al., 2018; Doolette et al., 2016; Durenkamp et al., 2016).

The main aim of this study was to assess the ecotoxicity of Ag introduced into the environment through SS land spreading. To create a more realistic scenario, we performed controlled lab-scale anaerobic digestion of Ag-spiked SS collected from a WWTP that was subsequently spread at realistic doses on fresh agricultural soil. Eisenia fetida earthworms and soil microorganisms were then subsequently exposed for 5 weeks to : 1) soil spiked with AgNPs (with or without SS); 2) soil spiked with $\mathrm{AgNO}_{3}$ (with or without SS); 3) control soil spiked with the dispersant used to disperse AgNPs (with or without SS); and 4) control soil without any additive (with or without SS). 
The novelty of our study is the combined analysis of the behavior of different key organisms in soil (earthworms and microorganisms) and Ag speciation to understand the underlying mechanisms of AgNP toxicity. The specific goals of this research were as follows:

1) To assess the impact of various Ag species on earthworms' life traits (mortality, body weight gain/loss, reproduction, expression of selected genes);

2) To assess the impact of various Ag species on soil microbial diversity and soil carbon respiration activity;

3) To understand how chemical transformation of $\mathrm{Ag}$ in $\mathrm{SS}$ influences $\mathrm{Ag}$ toxicity compared with direct exposure.

\section{Materials and methods}

\subsection{Earthworm test species}

Genetically identified E. fetida earthworms (Homa et al., 2015) were obtained from a laboratory breeding facility (LGCgE, University of Lille), where they were fed cow manure $a d$ libitum. Sub-adult earthworms were randomly selected, individually weighed, and introduced into the microcosms. The earthworms weighed $296 \mathrm{mg}$ on average (min: $104 \mathrm{mg}$, max: $751 \mathrm{mg}$, standard deviation: $95 \mathrm{mg}$ ).

\subsection{Soil}

Natural soil was collected in winter (January 2017) a few days before the beginning of the experiment. The soil was a slightly calcareous (presence of chalk granules) brown soil developed on wind-blown silts on chalky substrate, shallow to deep (DRAAF, 2013), from the Haut de France Region (France, GPS coordinates: 5059’94.87, 3¹5’04.75). The collection site has been used for vegetable production via certified organic agriculture since 2010, with no use of pesticides or chemical fertilizers in the last 10 years. For the study, the first $20 \mathrm{~cm}$ layer 
was collected and sieved at $5 \mathrm{~mm}$. The metal content of the soil was as follows: $2.57 \pm 1.97 \mathrm{mg}$ $\mathrm{kg}^{-1} \mathrm{Ag}, 19.97 \pm 0.35 \mathrm{mg} \mathrm{kg}^{-1} \mathrm{Cu}, 387.67 \pm 0.15 \mathrm{mg} \mathrm{kg}^{-1} \mathrm{Mn}, 1.30 \pm 1.19 \mathrm{mg} \mathrm{kg}^{-1} \mathrm{Ni}, 49.67 \pm$ $17.18 \mathrm{mg} \mathrm{kg}^{-1} \mathrm{~Pb}$, and $70.90 \pm 0.87 \mathrm{mg} \mathrm{kg}^{-1} \mathrm{mg} \mathrm{kg}^{-1} \mathrm{Zn}$. Cd was below the detection level $(0.5$ $\left.\mathrm{mg} \mathrm{kg}{ }^{-1}\right)$.

\subsection{Sewage sludge}

Four WWTPs situated in southern Poland were pre-selected in order to monitor the content of Ag during a two-year period. Among the four facilities, the facility that produced SS with the lowest level of contamination and a preferable $\mathrm{C}: \mathrm{N}$ ratio was selected. According to a previous study, SS from the selected WWTP is a good source of nutrients for earthworms without inducing stress related to the presence of contaminants ((Suleiman et al., 2017)). The selected WWTP (Poland, GPS coordinates: 50 55'22.81 1907'10.41) is a small-sized plant that uses activated sludge technology to support an agricultural area (flow: 1,000, population equivalents: 20,000). The metal content of the SS was as follows: $11.53 \pm 1.43 \mathrm{Ag}, 0.95 \pm 0.22$ $\mathrm{mg} \mathrm{kg}{ }^{-1} \mathrm{As}, 1.10 \pm 0.24 \mathrm{mg} \mathrm{kg}^{-1} \mathrm{Cd}, 140.62 \pm 22.55 \mathrm{mg} \mathrm{kg}^{-1} \mathrm{Cr}, 145.43 \pm 37.38 \mathrm{mg} \mathrm{kg}^{-1} \mathrm{Cu}$, $186.78 \pm 59.13 \mathrm{mg} \mathrm{kg}^{-1} \mathrm{Mn}, 19.11 \pm 9.02 \mathrm{mg} \mathrm{kg}^{-1} \mathrm{Ni}, 32.21 \pm 5.86 \mathrm{mg} \mathrm{kg}^{-1} \mathrm{~Pb}$, and $2510.36 \pm$ $615.99 \mathrm{mg} \mathrm{kg}^{-1} \mathrm{Zn}$ (average based on measurements between March and December 2016). Before agricultural reuse, anaerobic stabilization of the SS was performed at laboratory scale.

\subsection{Silver species}

The standard reference material Ag NM300K from the European Commission Joint Research Centre (JRC), which has been fully characterized (Klein et al., 2011), was used as the AgNPs in this study. The NPs were spherical and corresponded to a colloidal dispersion with a nominal $\mathrm{Ag}$ content of $10.2 \%$ by weight, dispersed in $4 \% \mathrm{w} / \mathrm{w} \%$ each of polyoxyethylene glycerol trioleate and polyoxyethylene sorbitan mono-laurate. The nominal size of $99 \%$ of the 
particles was approximately $15 \mathrm{~nm}$ without coating, and transmission electron microscopy (TEM) indicated a size of $17 \pm 8 \mathrm{~nm}$. Smaller nanoparticles of approximatively $5 \mathrm{~nm}$ were also present (Mendes et al., 2015). The commercial nanoparticle NM300K was kindly provided by the Fraunhofer Institute for Molecular Biology and Applied Ecology IME. Each bottle contained $2 \mathrm{~g}$ of NM300K, which was diluted in dispersant with a volume of $2 \mathrm{~mL}$; the resulting solution contained $10 \%(\mathrm{w} / \mathrm{w}) \mathrm{Ag}(0.1 \mathrm{~g}$ of $\mathrm{Ag}$ per $1 \mathrm{~mL}) . \mathrm{AgNO}_{3}$ solution was prepared by dissolving $\mathrm{AgNO}_{3}$ salt in sterile distilled water. The solutions of AgNPs and $\mathrm{Ag}$ ions (from $\mathrm{AgNO}_{3}$ ) were both diluted with milliQ water to obtain a Ag concentration of approximately 2 $\mathrm{mg} \mathrm{mL} \mathrm{L}^{-1}$.

\subsection{Experimental scheme}

\subsubsection{Anaerobic digestion of sewage sludge}

A batch anaerobic digestion of SS was performed in parallel in four continuous stirredtank bioreactors. In the first bioreactor, SS was introduced without any additives (AD-control). In the second, SS was spiked with $40 \mathrm{mg} \mathrm{L}^{-1} \mathrm{NM} 300 \mathrm{~K}$ AgNPs (AD-AgNPs). In the third, only a corresponding quantity of dispersant (AD-dis) was added to the SS, and in the fourth, $40 \mathrm{mg}$ $\mathrm{L}^{-1} \mathrm{AgNO}_{3}\left(\mathrm{AD}-\mathrm{AgNO}_{3}\right)$ was added. The selected $\mathrm{Ag}$ concentration in the bioreactors was based on the maximum concentration of Ag that does not disturb anaerobic fermentation (Yang et al., 2012) (Full justification in SI 1)

The bioreactors were glass vats filled with $6 \mathrm{~L}$ of SS maintained under mesophilic conditions at a temperature of $37^{\circ} \mathrm{C}$ with constant mixing $(180 \mathrm{rpm})$ using a mechanical stirrer. Details of the equipment as well as the methods of analyzing $\mathrm{pH}$, volatile fatty acids, volatile solids, total solids, and ammonium nitrogen were described previously (Grosser, 2017). After 4 weeks of anaerobic digestion (AD), the process had stabilized; the bioreactors were then stopped, and the digestates were centrifuged at $12100 \mathrm{rcf}$ for 15 minutes. 


\subsubsection{Microcosm exposure - experimental mixtures}

Earthworms and soil microbial communities were exposed in microcosms subjected to 8 treatments (at three different concentrations) in triplicate over 5 weeks (Figure SI 2).

a) Four of the treatments corresponded to indirect exposure, i.e., mixed with SS ("AD-X"). A realistic application quantity of SS was introduced to the microcosms in a single addition. In France, the maximum dose of SS spreadable over 10 years (Circular DE / GE $\mathrm{n}{ }^{\circ} 357$ of 03/16/99, 1999) was divided by 10 , and quantities equivalent to 3,6 and 10 times this calculated quantity were applied. The details of the selection of these quantities of SS for addition to the microcosms are given in SI 3. The three different dosages of SS were as follows: $60 \mathrm{~g}$ of fresh SS per kg of fresh soil as the 3-year perspective, "perspective 3" (3y); $120 \mathrm{~g} \mathrm{~kg}^{-1}$ as the 6-year perspective, "perspective 6" (6y); and $200 \mathrm{~g} \mathrm{~kg}^{-1}$ for the 10 -year perspective, "perspective 10" (10y). The amount of Ag remaining in the SS after the fermentation process was estimated as $0.233 \mathrm{mg}$ of Ag per $\mathrm{g}$ of fresh SS. Thus, the estimated amount of $\mathrm{Ag}$ was 14,28 and $47 \mathrm{mg} \mathrm{kg}^{-}$

${ }^{1}$ (fresh matter) for perspectives 3,6 , and 10, respectively (details of this estimation are provided in SI 4). The mean humidity of soil mixtures was $21 \%$ therefore, the estimated amount of $\mathrm{Ag}$ in dry mixtures was 18,35 and $59 \mathrm{mg} \mathrm{kg}^{-1}$ (dry matter). The microcosms were filled with $1 \mathrm{~kg}$ of these mixtures.

- AD-AgNPs condition: soil supplied with SS digested with AgNPs in dispersant (AD-AgNPs3y, AD-AgNPs-6y, AD-AgNPs-10y);

- AD-dis: soil supplied with SS digested with dispersant solution consisting 4\% w/w\% each of polyoxyethylene glycerol trioleate and polyoxyethylene sorbitan mono-laurate (AD-dis-3y, AD-dis-6y, AD-dis-10y); 
- $\mathrm{AD}-\mathrm{AgNO}_{3}$ : soil supplied with $\mathrm{SS}$ digested with $\mathrm{AgNO}_{3}\left(\mathrm{AD}-\mathrm{AgNO}_{3}-3 \mathrm{y}, \mathrm{AD}-\mathrm{AgNO}_{3}-6 \mathrm{y}\right.$, $\left.\mathrm{AD}-\mathrm{AgNO}_{3}-10 \mathrm{y}\right)$

- AD-control: soil supplied with SS digested without any addition (AD-control-3y, AD-control6y, AD-control-10y).

b) Four treatments corresponded to direct exposure (i.e., without addition of SS). As in the microcosms with SS, 14, 28 and $47 \mathrm{mg} \mathrm{kg}^{-1}$ (fresh matter) of $\mathrm{Ag}$ was added to perspectives 3, 6, and 10, respectively, but this Ag was added directly to the soil.

- AgNPs: soil supplemented with a solution of AgNPs in dispersant (AgNPs-3y, AgNPs-6y, AgNPs-10y);

- Dis: soil supplemented with the corresponding volume of dispersant (Dis-3y, Dis-6y, Dis$10 \mathrm{y})$

- $\mathrm{AgNO}_{3}$ : soil supplemented with $\mathrm{AgNO}_{3}$ solution $\left(\mathrm{AgNO}_{3}-3 \mathrm{y}, \mathrm{AgNO}_{3}-6 \mathrm{y}, \mathrm{AgNO}_{3}-10 \mathrm{y}\right)$

- Control: soil without any addition.

The mixtures were prepared as described above and distributed into plastic boxes with perforated lids (18 x $18 \times 9 \mathrm{~cm}), 1 \mathrm{~kg}$ of fresh matter per box. Twelve earthworms were introduced per microcosm. The soil and earthworms were analyzed before the experiment and after 5 weeks of exposure. A subsample of fresh soil was stored at $-18{ }^{\circ} \mathrm{C}$ before microbial DNA extraction and at $4^{\circ} \mathrm{C}$ for microbial respiration analysis.

\subsection{Analysis}

2.6.1. Biological analysis

Life traits of earthworms: reproduction, survival and biomass 
Reproduction potential was estimated by counting cocoons and juveniles at the end of the exposure period and observing the viability of the collected cocoons. Survival was measured by counting earthworms that survived exposure. The biomass of the groups of earthworms was measured before and after exposure. To compensate for the initial differences in biomass between the microcosms, the final biomass value was expressed as a percentage.

\section{Gene expression levels in earthworms}

Coelomocytes of earthworms were collected by extrusion as described previously (Brulle et al., 2006). Extrusion is a non-invasive method (Diogène et al., 1997; Eyambe et al., 1991) that involves electrical stimulation of earthworms in a cold environment. Stress causes the expulsion of coelomocytes by nephridial pores. Then, RNA was extracted from the coelomocytes following the Tri-Reagent ${ }^{\circledR}$ protocol (Molecular Research Center, USA). Reverse transcription was performed using $1.5 \mu \mathrm{g}$ of RNA with the Omniscript RT kit (Qiagen, Netherlands), RNase inhibitor (Thermo Fisher Scientific, USA) and primers (Invitrogen and Thermo Fisher Scientific, USA). Quantitative PCR were performed with the MESA Blue qPCR MasterMix Plus for SYBR ${ }^{\circledR}$ Assay no ROX kit (Eurogentec, France). The qPCR conditions were as follows: denaturation at $95^{\circ} \mathrm{C}$ for $5 \mathrm{~min}, 40$ cycles of amplification and extension (each cycle comprising $3 \mathrm{sec}$ at $95^{\circ} \mathrm{C}, 30 \mathrm{sec}$ at $60^{\circ} \mathrm{C}$ and $10 \mathrm{sec}$ at $72^{\circ} \mathrm{C}$ ), a melting curve step (progressive heating from 60 to $95^{\circ} \mathrm{C}$ ), and then cooling to reach $40^{\circ} \mathrm{C}$. Two previously validated reference genes were used: $\beta$-actin (Forward 5'-GTACGATGAGTCCGGG-3' and 5'GCATGTGTGTGTGGTGTC-3') and the ribosomal protein S13 (Forward 5'CGCACGGTTTTAGTTTCT-3' and Reverse 5'-CCATGCGAGTCTCGAAG-3') (Bernard et al., 2010). The gene encoding $\beta$-actin (an intracellular eukaryotic protein) is the most commonly used housekeeping gene for qPCR quantification. The gene encoding ribosomal protein S13 (RPS13) has also been used previously as a housekeeping gene (Rorat et al., 2017). Three target 
genes were tested: superoxide dismutase (sod) (Forward 5'-GGCGATAACACAAATGGT-3'

244 and Reverse 5'-CGTGCGTCCAATGATTGAA-3'), lysenin (lys) (Forward 5'245 CGGCAACAAACGTCTAC-3' and Reverse 5'-GTGAAATACAGGCAGAAG-3') and $c d$ metallothionein (cdmt) (Forward 5'-CGCAAGAGAGGGATCAACTT-3' and Reverse 5'CTATGCAAAGTCAAACTGTC-3'). These genes are often used as biomarkers in earthworms. The sod gene is associated with oxidative stress (Choi and Park, 2015). The SOD protein catalyzes the destruction of hydrogen peroxide, a molecule created during oxidative stress that is dangerous for cells (Bernard et al., 2015). The lysenin gene is required for the synthesis of

251 the hemolytic protein LYS, which is involved in immunity and associates with sphingomyelin to permit membrane pore formation (Bernard et al., 2010). LYS is a key protein in the secretome of coelomocytes (Hayashi et al., 2015). Finally, the $c d m t$ gene plays a role in early defense against toxic metal ions and oxidative stress (Hayashi et al., 2013); this gene is a good biomarker of exposure to heavy metals because its expression increases during exposure to $\mathrm{Cd}$ in particular but also other metallic elements (Höckner et al., 2011). The reactions were performed using a LightCycler®480 with LightCycler Software (Roche Diagnostics, France). The geometric mean of the two reference genes was used (Brulle et al., 2006). The relative expression of each gene of interest was calculated using the formula of Pfaffl (Livak and Schmittgen, 2001): $\mathrm{R}=2^{- \text {(CPtarget-CPref) }}$. The induction factor corresponds to $\mathrm{R}_{\text {treatment }} / \mathrm{R}_{\text {associated }}$ treatment without silver.

\section{Microbial community composition}

DNA was extracted from $500 \mathrm{mg}$ of sieved soil using a PowerSoil ${ }^{\circledR}$ DNA Isolation kit (Qiagen, France) according to the manufacturer's instructions. The V4-V5 hypervariable region of the 16S rRNA gene targeting Bacteria and Archaea was amplified using the primers 515F (5'-GTGYCAGCMGCCGCGGTA-3') and 928R (5'-CCCCGYCAATTCMTTTRAGT-3'). 
The reaction mixture included $1.40 \mu \mathrm{L}$ of each primer $(20 \mu \mathrm{M}$ each), $28 \mu \mathrm{L}$ of AmpliTaq Gold Master mix (AmpliTaq Gold; 360 Master Mix Applied Biosystems), $2 \mu \mathrm{L}$ of template DNA at a concentration of $5 \mathrm{ng} \mu \mathrm{L}^{-1}$ and water qsp $55 \mu \mathrm{L}$. The cycle conditions included initial denaturation at $94^{\circ} \mathrm{C}$ for $10 \mathrm{~min}$, followed by 35 cycles of denaturation at $95^{\circ} \mathrm{C}$ for $30 \mathrm{~s}$, annealing at $65^{\circ} \mathrm{C}$ for $30 \mathrm{~s}$ and extension at $72{ }^{\circ} \mathrm{C}$ for $40 \mathrm{~s}$ and an additional extension step at $72{ }^{\circ} \mathrm{C}$ for 10 min after cycling was complete. Illumina MiSeq sequencing was performed using the $2 \times 250$ paired-end protocol with an Illumina ${ }^{\circledR}$ MiSeq instrument at the GeT plage facility, Toulouse, France (http://get.genotoul.fr).

\section{Potential carbon respiration}

The potential carbon respiration rate is also called substrate-induced respiration and is measured under optimal conditions of temperature and substrate (Anderson and Domsch, 1978). Briefly, fresh soil equivalent to $10 \mathrm{~g}$ of oven-dried soil was placed in a sterile $150 \mathrm{ml}$ plasma flask with a rubber stopper. One milliliter of glucose was added to obtain a final concentration of $3 \mathrm{mg}$ glucose $\mathrm{g}^{-1}$ dry soil. Additional water was added to achieve $70 \%$ of the water holding capacity. The plasma flasks were closed and incubated at $28{ }^{\circ} \mathrm{C}$ for $3.5 \mathrm{~h}$. Gas samples were analyzed at $0,1,2,3$, and $3.5 \mathrm{~h}$ for $\mathrm{CO}_{2}$ concentration using a gas chromatograph (P200 Micro, Agilent Technology, Massy, France).

\subsubsection{Physicochemical analysis}

\section{Metal content in earthworms and soils}

On day zero of exposure, some earthworms from the breeding facility were sacrificed to measure the quantities of metals present in their bodies. After Ag exposure, earthworms from each microcosm were sacrificed for the same purpose. Before sacrifice, a depuration phase of $24 \mathrm{~h}$ was conducted in order to empty the intestinal content. The organisms were sacrificed by 
freezing for at least $48 \mathrm{~h}$ and then lyophilized by group from the same microcosm for approximately $60 \mathrm{~h}$. The samples were ground to a powder using liquid nitrogen and then mineralized by acid digestion (using $\mathrm{HNO}_{3}, \mathrm{H}_{2} \mathrm{SO}_{4}$ and $\mathrm{HCl}_{4}$ ) at high temperature as described by Bernard et al. (9). The resulting solution was analyzed by ICP-OES (inductively coupled plasma-optical emission spectrometry) (Varian 720-ES, USA) to quantify $\mathrm{Cd}, \mathrm{Co}, \mathrm{Cu}, \mathrm{Mn}, \mathrm{Ni}$, $\mathrm{Pb}, \mathrm{Zn}$ and $\mathrm{Ag}$.

Soil samples, SS samples and mixed samples were collected and lyophilized at the beginning and end of exposure. The dried samples were ground with a mortar and pestle. For mineralization, $300 \mathrm{mg}$ of sample was digested in $7 \mathrm{~mL}$ of concentrated $\mathrm{HNO}_{3}$ using a Berghof microwave digestion system (speed wave MWS-2-Microwave pressure digestion). The resulting solution was analyzed by ICP-OES (Thermo apparatus) to quantify $\mathrm{Cd}, \mathrm{Co}, \mathrm{Cu}, \mathrm{Mn}$, $\mathrm{Ni}, \mathrm{Pb}, \mathrm{Zn}$, and $\mathrm{Ag}$.

\section{Speciation of silver in earthworms and soils}

Samples of earthworms and the mixtures of soil and SS were analyzed to determine the chemical state of Ag. Ag speciation was determined by X-ray absorption spectroscopy. Ag Kedge (25.514 keV) XANES (X-ray absorption near-edge structure) spectra were acquired at the European Synchrotron Radiation Facility (ESRF, France) on the FAME beamline (BM30b) with $\mathrm{Si}(220)$ monochromator crystals ((Proux et al., 2005)).

Prior to analysis, the samples were lyophilized, ground and pressed into $5 \mathrm{~mm}$ pellets. Spectral acquisition was performed at liquid helium temperature to avoid sample evolution under the beam. Measurements were carried out in fluorescence mode using a 30 -element Canberra Ge solid-state detector. Each spectrum was the sum of at least three scans. A set of model compounds including metallic Ag (AgNPs), Ag-humic acids (Ag-HA), $\mathrm{Ag}_{2} \mathrm{~S}, \mathrm{Ag}-$ thiocarbamate (Ag-thiocarb) and Ag-glutathione (Ag-GSH) (the last two corresponding to 
thiolated compounds linked to $\mathrm{Ag}$ ) was run in transmission mode. Normalization and data reduction were performed according to standard methods using Athena software ((Ravel and Newville, 2005)).

The residual factor of linear combination fitting was calculated as follows: $\mathrm{R}=\sum$ (expfit $)^{2} / \sum(\exp )^{2}$, where the sums are over the data points in the fitting region. At each step of the fitting, an additional reference spectrum was added if the following two conditions were true: the $\mathrm{R}$ factor decreased by $20 \%$ or more and the additional reference had a contribution equal to or greater than $10 \%$ among $\mathrm{Ag}$ species.

\subsection{Bioinformatics analysis of microbial communities}

Sequence analysis was performed with the pipeline FROGS from the Galaxy portal of the Toulouse Midi-Pyrenees bioinformatics platform (Escudié et al., 2018). After a preprocessing step that included quality filtering, read trimming and read assembly, the sequences were clustered with Swarm (Mahé et al., 2014) with an aggregation distance of 3 and a denoising clustering step. Chimeras were removed using VSEARCH (Rognes et al., 2016) combined with original cross-sample validation. Operational taxonomic units (OTUs) with abundances lower than $0.005 \%$ were removed (Bokulich et al., 2013). SILVA database 128 (release date 29.09.2016) was used to perform the OTU affiliations (Quast et al., 2013). In order to compare samples, a normalization procedure was performed with random resampling down to 14,165 sequences.

\subsection{Statistical analysis}

The majority of the earthworm biomass, mortality, gene expression and metal content data did not follow a normal distribution, and the variances were not homogeneous between treatments (Shapiro-Wilk, Lilliefors and Bartlett tests). Thus, Sheirer-Ray-Hare nonparametric 
tests and post-hoc tests based on ranks were used. When data fulfilled statistical assumption of parametric tests (normality and homogeneity of variances), analysis of variance (ANOVA) and Tukey HSD (honestly significant difference) post-hoc tests were used. Correlation matrices (based on the Kendall method) were constructed.

For microorganism analyses, one-way ANOVA and Tukey tests were performed with the software PAST (Hammer et al., 2001) to determine if there were significant differences in respiration between the treatments. Microbial community composition was analyzed using PRIMER software (PRIMER-E Ltd., Plymouth, UK). Dissimilarity in OTU composition between all pairs of microbial communities was computed using Bray-Curtis distance and nonparametric permutational multivariate analysis of variance (PerMANOVA) (Anderson, 2001) was conducted to test for difference in composition among treatments. PerMANOVA was performed using permutation tests with 9,999 iterations. Results of the PerMANOVAs were visualized using non-metric multidimensional scaling ordinations (NMDS) based on Bray-Curtis distances. Finally, an indicator analysis (IndVal) (Dufrene and Legendre, 1997) was carried out to estimate the degree of association between OTUs and treatments. The analysis quantifies the fidelity and specificity of species (OTU) in relation to treatments or to groups of treatments, i.e., with or without SS on one hand and with or without Ag on the other hand, and tests for the statistical significance of the associations using permutation tests with 9,999 iterations (De Cáceres et al., 2010; Dufrene and Legendre, 1997). The indicator value of species $\mathrm{i}$ for class $\mathrm{j}$ is obtained using the equation $\operatorname{IndVal}_{\mathrm{ij}}=100 \cdot \mathrm{A}_{\mathrm{ij}} \cdot \mathrm{B}_{\mathrm{ij}}$, where $\mathrm{A}_{\mathrm{ij}}$ is specificity, i.e., the proportion of the individuals of the species $i$ that are in the class $j$, and $B_{i j}$ is fidelity, i.e., the proportion of sites in the class $\mathrm{j}$ that contain the species $\mathrm{i}$.

Unless otherwise mentioned, statistical analyses were implemented within the R programming environment (R Core Team, 2008). 


\subsection{Biological analysis}

3.1.1. Life traits: reproduction, survival and biomass

The percentage of survival of earthworms after exposure are presented in Table 1.

372 Statistical tests showed no significant differences between any of the treatments and their

373 respective controls without $\mathrm{Ag}$ (i.e. the control of $\mathrm{AgNPs}$ is Dis, for $\mathrm{AgNO}_{3}$ it is Control, for $\mathrm{AD}-\mathrm{AgNPs}$ it is $\mathrm{AD}$-dis and for $\mathrm{AD}-\mathrm{AgNO}_{3}$ it is $\mathrm{AD}$-control). $\mathrm{Ag}$ did not cause mortality under these conditions. A significant impact of SS addition was observed in treatment AD-X-10y (perspective 10) with or without Ag. The addition of the highest dose of digested SS led to the death of all earthworms living in the microcosms.

Table 1: Mean percentage of survival in the microcosms. Standard deviations are indicated.

\begin{tabular}{|l|r|r|r|}
\hline & $\begin{array}{l}\text { Survival \% in } \\
\text { Perspective 3 }\end{array}$ & $\begin{array}{c}\text { Survival \% in } \\
\text { Perspective 6 }\end{array}$ & \multicolumn{1}{c|}{$\begin{array}{c}\text { Survival \% in } \\
\text { Perspective 10 }\end{array}$} \\
\hline Control & $100.0 \pm 0.0$ & $97.2 \pm 4.8$ & $100.0 \pm 0.0$ \\
\hline Dis & $100.0 \pm 0.0$ & $100.0 \pm 0.0$ & $97.2 \pm 4.8$ \\
\hline $\mathrm{AgNPs}$ & $100.0 \pm 0.0$ & $100.0 \pm 0.0$ & $100.0 \pm 0.0$ \\
\hline $\mathrm{AgNO}_{3}$ & $100.0 \pm 0.0$ & $100.0 \pm 0.0$ & $01.7 \pm 14.4$ \\
\hline $\mathrm{AD}-$ control & $100.0 \pm 0.0$ & $100.0 \pm 0.0$ & $0.0 \pm 0.0$ \\
\hline $\mathrm{AD}-$ dis & $100.0 \pm 0.0$ & $100.0 \pm 0.0$ & $0.0 \pm 0.0$ \\
\hline $\mathrm{AD}-\mathrm{AgNPs}$ & $100.0 \pm 0.0$ & $95.8 \pm 5.9$ & $0.0 \pm 0.0$ \\
\hline $\mathrm{AD}-\mathrm{AgNO}_{3}$ & $100.0 \pm 0.0$ & $100.0 \pm 0.0$ & 0.0 \\
\hline
\end{tabular}

380 From the second week of exposure, cocoons were observed in certain microcosms, and from the 4th week, juveniles were born. The reproduction was also not affected by Ag, regardless of

382 its chemical form, since there was no significant difference between the number of cocoons or

383 juveniles in Ag treatments compared to respective controls without Ag (Table 2). However, there were significant differences between the treatments with SS and those without SS. Almost no reproduction was observed in the microcosms without SS, while in the microcosms with SS, breeding was significant, and the cocoons were viable. 
Table 2: Number of cocoons and juveniles in the microcosms. Standard deviations are indicated. Empty cells in the table

corresponds to data no available because of the high mortality in theses conditions.

\begin{tabular}{|l|c|c|c|c|c|c|}
\hline & \multicolumn{3}{|c|}{ Cocoons } & \multicolumn{3}{c|}{ Juveniles } \\
\hline & Perspective 3 & Perspective 6 & Perspective 10 & Perspective 3 & Perspective 6 & Perspective 10 \\
\hline Control & $0 \pm 0$ & $0 \pm 0$ & $0 \pm 0$ & $0 \pm 0$ & 0 & $0 \pm 0$ \\
\hline Dis & $0 \pm 0$ & $0 \pm 0$ & $0 \pm 0$ & $0 \pm 0$ & 0 & $0 \pm 0$ \\
\hline AgNPs & $0 \pm 0$ & $1 \pm 1$ & $0 \pm 0$ & $0 \pm 0$ & $2 \pm 2$ & $0 \pm 0$ \\
\hline AgNO 3 & $0 \pm 0$ & $0 \pm 0$ & $0 \pm 0$ & $0 \pm 0$ & $1 \pm 1$ & $0 \pm 0$ \\
\hline AD-control & $13 \pm 7$ & $3 \pm 1$ & - & $5 \pm 2$ & 0 & - \\
\hline AD-dis & $7 \pm 2$ & $18 \pm 3$ & - & $5 \pm 2$ & 2 & - \\
\hline AD-AgNPs & $6 \pm 2$ & $10 \pm 2$ & - & $3 \pm 2$ & $1 \pm 1$ & - \\
\hline AD-AgNO 3 & $32 \pm 12$ & $15 \pm 9$ & - & $5 \pm 2$ & $3 \pm 1$ & - \\
\hline
\end{tabular}

The changes in earthworm biomass observed during exposure are presented in Figure 1.

391 In all treatments, body weight gain or loss was not significantly different from that in the

392 respective control treatments. Thus, no effect of $\mathrm{Ag}$ (nano or ionic, added directly or via

393 fermented SS) on earthworm biomass was observed. However, there were some significant

394 differences between treatments. Earthworms exposed to treatments without SS lost up to $31 \%$

395 of body weight showing a stress, while worms exposed to treatments with SS gained considerable weight (between 34 and 176\%). 


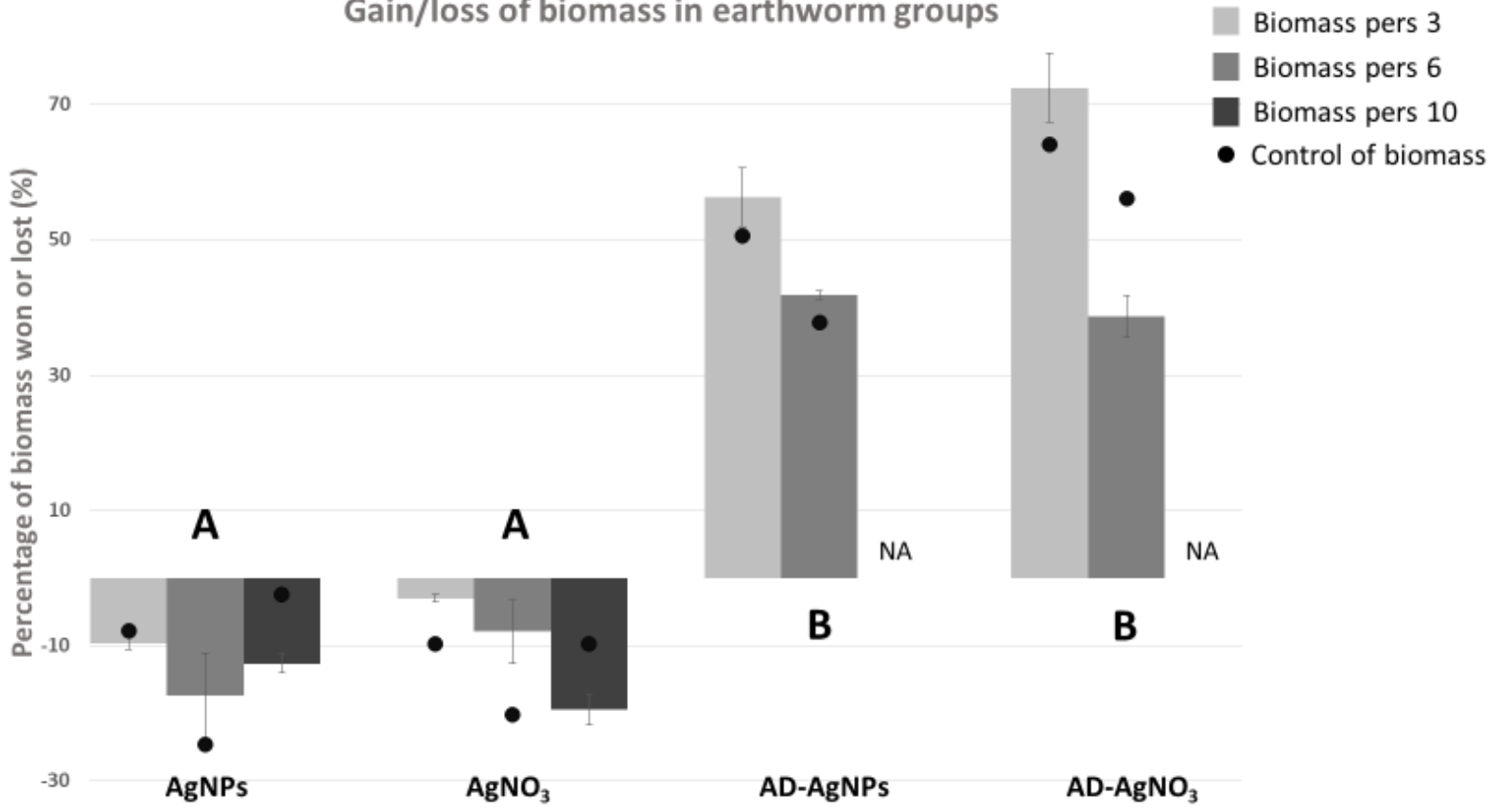

Figure 1: Percentage of weight gain or loss in the groups of earthworms in the microcosms between the beginning and end of

the experiment (percentages are reported to compensate for differences in initial weight). Each perspective is represented by

a color: light grey for perspective 3, medium grey for perspective 6 and dark grey for perspective 10. The black dots correspond

to the mean earthworm biomass under control conditions (dispersant for $A g N P S$, control for $A g N O_{3}$, AD-dis fir $A D-A g N P S$ and $A D$-control for AD-AgNO3). NA corresponds to non-available data due to the high mortality in these conditions. The big letters show the differences between conditions $A g N P S, A g N O_{3}, A D-A g N P s$ and $A D-A g N O_{3}$ (all perspectives combined). There were no differences between perspectives within the same condition.

3.1.2. Gene expression levels in earthworms

411 of 3 target genes were analyzed in two ways: with both reference genes as all other data and

412 with only one reference gene (Actin) like in the publications of Brulle et al. (2011) and Homa et al. (2015). The obtained results were similar. 
The analysis of gene expression showed no significant variations in the 3 target genes: lys, sod and $c d m t$ (Figures SI 5, SI 6 and SI 7). SS and Ag did not induce the transcription of these 3 genes for these 3 concentrations.

\subsubsection{Potential carbon respiration}

All microorganism activity and diversity measurements were performed only for perspective 3. After direct exposure to $\mathrm{Ag}\left(\mathrm{AgNPs}\right.$ or $\left.\mathrm{AgNO}_{3}\right)$ in soil, a strong and significant decrease in potential carbon respiration was observed compared to the control and dispersanttreated soils. There was no effect of Ag form initially added in soil because the impact of AgNPs and $\mathrm{AgNO}_{3}$ was similar on the potential respiration. No effect on potential carbon respiration was observed when $\mathrm{Ag}\left(\mathrm{AgNPs}\right.$ or $\mathrm{AgNO}_{3}$ ) was applied on soil via SS (Figure 2), with a positive effect of SS application on microbial carbon respiration.

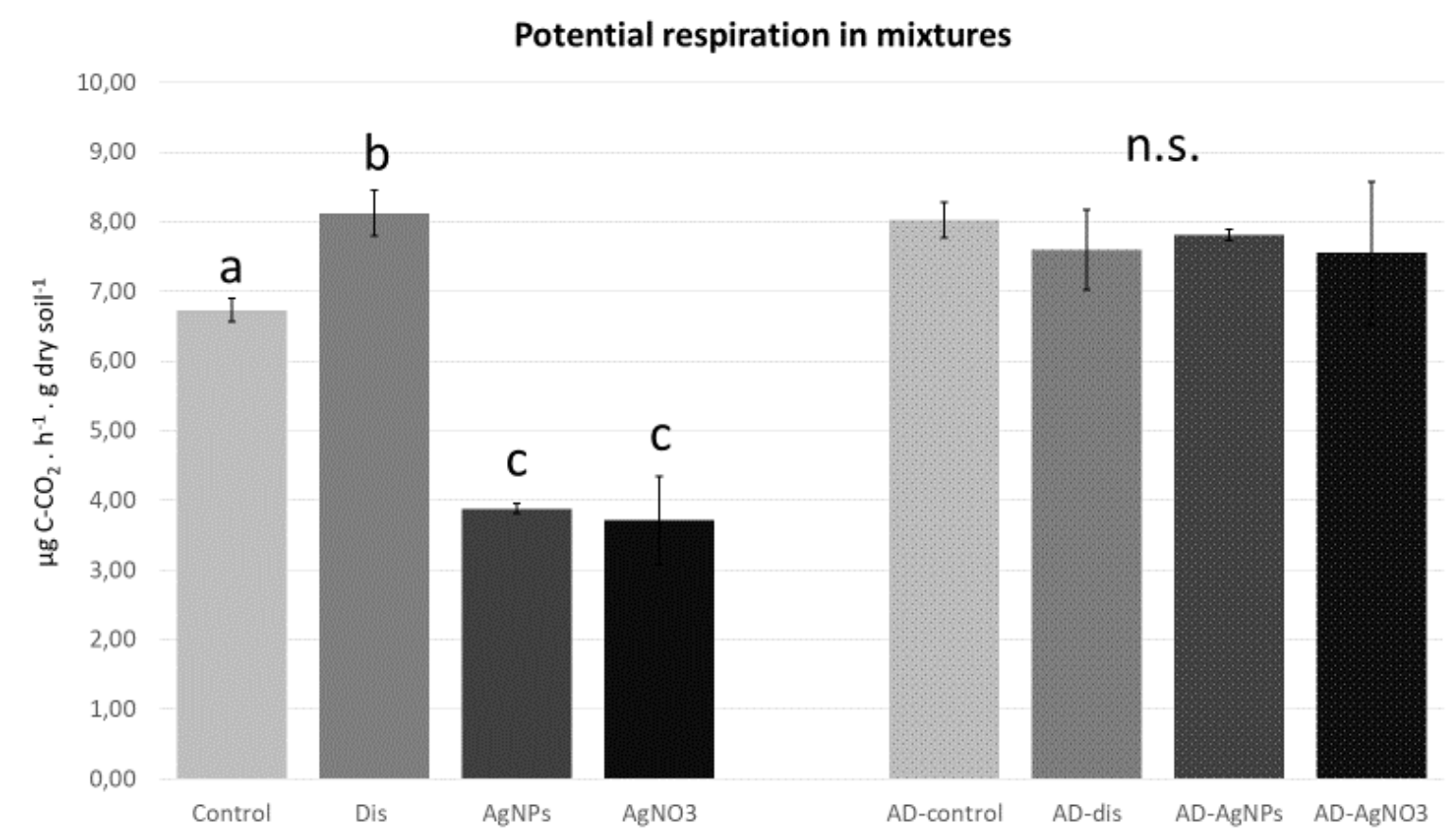

Figure 2: Potential carbon respiration of microbial communities in mixtures ( $\mu \mathrm{g} C-\mathrm{CO}_{2} \cdot h^{-1} \cdot \mathrm{g}^{-1}$ of dry soil). The letters indicate significant differences in respiration between the 4 treatments without sewage sludge. "n.s." indicates that there were no 
3.1.4. Microbial community composition

After 5 weeks of the experiment, microbial community composition differed greatly

434

435 depending on the presence or absence of SS. The addition of SS explained $52 \%$ of the variance between these 2 groups (Figure 3). Ag addition (with or without SS) explained another $12 \%$ of the variance. Interactions between routes of entry (direct exposure or via SS application) and $\mathrm{Ag}$ form (AgNPs or $\left.\mathrm{AgNO}_{3}\right)$ explained $12 \%$ of the variance.

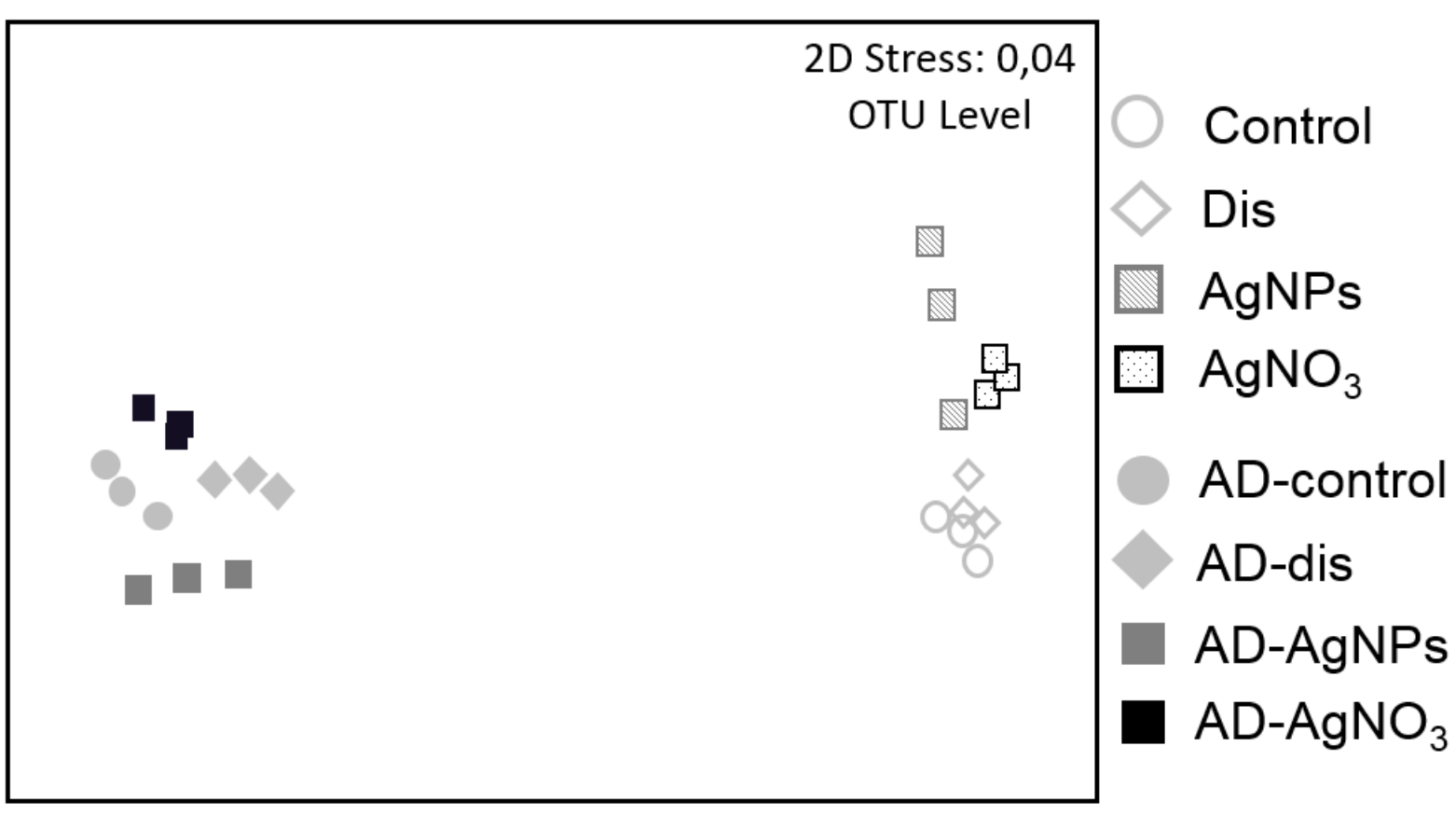

Figure 3: Two-dimensional ordination solution using non-metric multidimensional scaling (NMDS) based on the Bray-Curtis distance showing the relative proximities of microbial community composition among all treatments.

The IndVal analysis (based on 519 OTU) failed to extract any indicator of Ag exposure at the species or genus level (Table SI 8). However, the Indval analysis based on samples supplied with or without SS led to identify 118 microorganisms indicating of SS supply. Among them, we found 9 Archaea from the Methanobacteriales and Methanomicrobiales orders and 109 bacteria from families and orders often found in anaerobic environments and gastrointestinal 
tract of different animals. For instance, we identified 22 members of Clostridiales all known as obligate anaerobes and several representatives of the Porphyromonadaceae, Rikenellaceae families.

\subsection{Physicochemical analysis}

3.2.1. Metal content in mixtures

The soil concentrations of Ag were lower than expected (Table 3). The average soil Ag concentrations in perspectives 3,6 and 10 were $11.56 \pm 1.69 \mathrm{mg} \mathrm{kg}^{-1}, 16.97 \pm 3.99 \mathrm{mg} \mathrm{kg}^{-1}$ and $25.38 \pm 3.69 \mathrm{mg} \mathrm{kg}^{-1}$, respectively. In perspectives 3 and 10, the Ag concentrations in ADAgNPs, $\mathrm{AD}-\mathrm{AgNO}_{3}, \mathrm{AgNPs}$ and $\mathrm{AgNO}_{3}$ were similar. In perspective 6, there was a slight difference in Ag concentrations between the treatments with direct addition of $\mathrm{Ag}$ and those with addition of Ag via SS.

Table 3: Silver concentration in mixtures ( $\mathrm{mg} \mathrm{kg}^{-1}$ of dry mixture). Results were obtained by ICP analysis. Standard deviations are indicated. Some standard deviations are missing due to a lack of replicates.

\begin{tabular}{|c|r|r|r|}
\hline Condition & Perspective 3 & Perspective 6 & Perspective 10 \\
\hline AD-control & $2.00 \pm 0.61$ & $1.71 \pm 0.23$ & $4.57 \pm 0.86$ \\
\hline AD-AgNPs & $9.54 \pm 0.52$ & $15.00 \pm 1.56$ & $23.77 \pm 1.48$ \\
\hline AD-dis & $3.69 \pm 0.80$ & 2.15 & $27.97 \pm 5.25$ \\
\hline AD-AgNO3 & $11.63 \pm 0.23$ & 12.60 & $27.40 \pm 2.55$ \\
\hline AgNPs & $11.23 \pm 0.84$ & $17.9 \pm 1.95$ & $0.94 \pm 0.87$ \\
\hline Dis & $2.55 \pm 0.35$ & $0.45 \pm 0.41$ & $22.37 \pm 2.20$ \\
\hline AgNO & $13.83 \pm 0.78$ & $22.37 \pm 1.76$ & \\
\hline Control & & & \\
\hline
\end{tabular}

\subsubsection{Metal content in earthworms}


The contents of 7 metals in earthworms were analyzed after exposure (Table SI 9). Since the organisms exposed to SS in perspective 10 did not survive, metal content data were not available for these microcosms. No significant variation in $\mathrm{Pb}$ and $\mathrm{Zn}$ was observed regardless of the treatment and perspective. $\mathrm{Cd}, \mathrm{Cu}$, and $\mathrm{Mn}$ were bioaccumulated differently by the earthworms depending on exposure to SS, with greater bioaccumulation in the presence of SS. However, there was no impact of $\mathrm{Ag}$ on the bioaccumulation of these metals. The concentrations of $\mathrm{Cu}$ and $\mathrm{Mn}$ in worms increased with their concentrations in the soil (presence or absence of SS in the microcosms). Conversely, the bioaccumulation of Cd was lower in the presence of higher concentrations of $\mathrm{Cd}$ in the soil.

In all treatments without $\mathrm{Ag}$ addition, the $\mathrm{Ag}$ content in earthworms was below the detection level. Bioaccumulation of $\mathrm{Ag}$ in earthworms was significant when they were exposed to microcosms directly contaminated with Ag (Figure 4). In microcosms with SS application, Ag bioaccumulation in earthworms was significant only in the condition $\mathrm{AD}-\mathrm{AgNO}_{3}-6 \mathrm{y}$ and was detectable in AD-AgNPs-3y, AD-AgNPs-6y and $\mathrm{AD}-\mathrm{AgNO}_{3}-3 \mathrm{y}$.

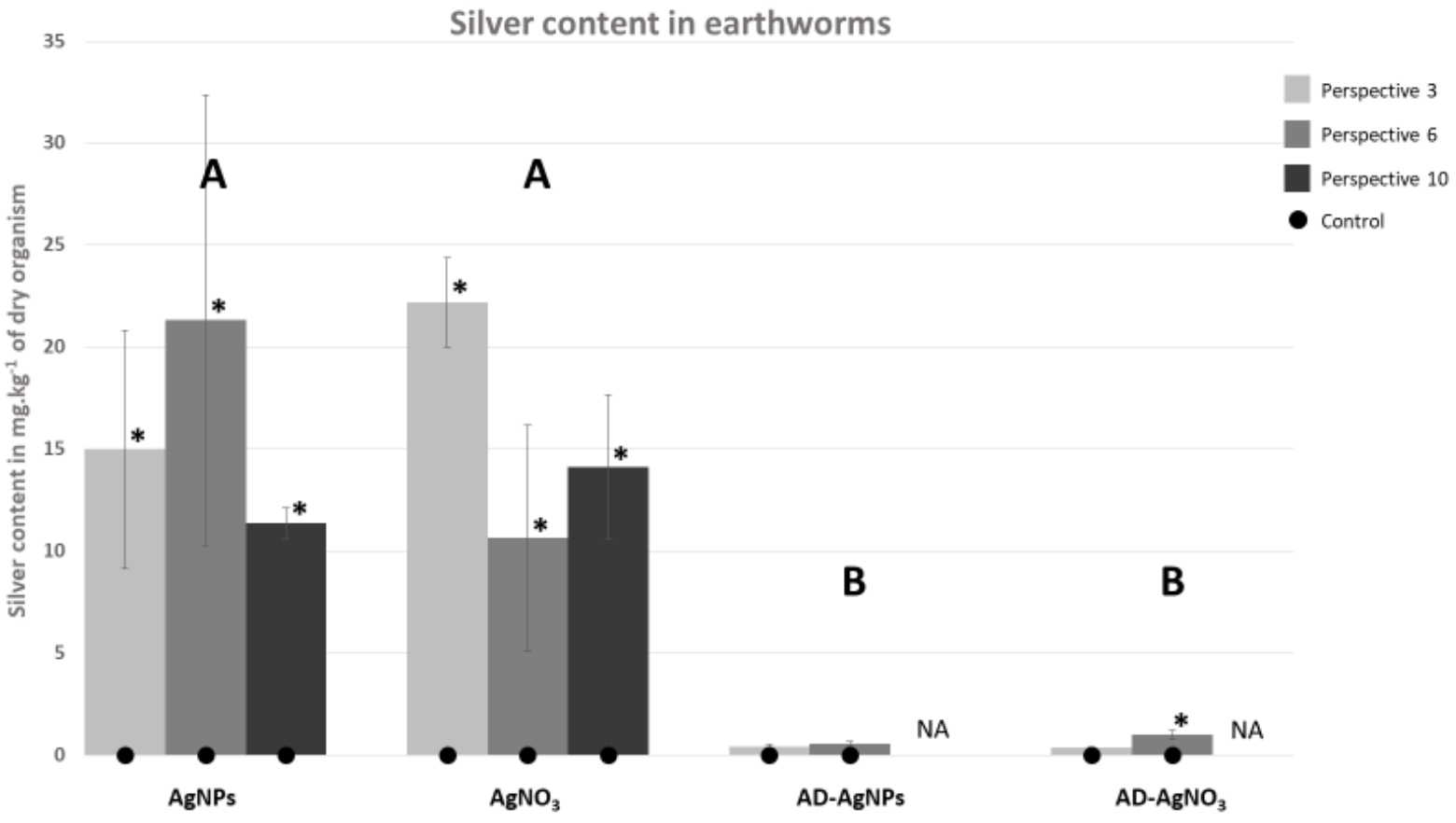


481

482

483

484

485

486

487

488

489

490

491

492

493

494

495

496

497

498

499

Figure 4: Silver content in earthworms ( $m g$ of $\mathrm{Ag} \mathrm{kg}^{-1}$ of dry matter). Each perspective is represented by a color: light grey for perspective 3, medium grey for perspective 6 and dark grey for perspective 10. NA means data are non-available due to the $\underline{\text { high mortality in these conditions. The big letters indicate significant differences among conditions } A g N P s, A g N O_{3}, A D-A g N P S}$ and $\mathrm{AD}-\mathrm{AgNO}_{3}$ (no difference between perspectives within the same condition). The black dots correspond to the mean biomass of earthworms in the control (dispersant for $\mathrm{AgNPS}$ and control for $\mathrm{AgNO}_{3}$ ). The stars $\left(^{*}\right)$ indicate significantly different values compared with the associated control without silver.

\subsubsection{Speciation of silver in soil}

AgNPs and $\mathrm{AgNO}_{3}$ in soil

In the absence of SS, initially (approximately $2 \mathrm{~h}$ after spiking), the speciation of $\mathrm{Ag}$ varied depending on its initial form (Figure 5). Ag initially from AgNPs was mainly in its pristine form ( $76 \%$ metallic Ag), with the remainder bound to organic matter (24\%). This latter fraction was probably the fraction of soluble Ag that quickly dissolved and was complexed by the organic matter present in the soil. The $\mathrm{Ag}$ initially from $\mathrm{AgNO}_{3}$ was quickly complexed with organic matter with a fraction of thiol groups (21\% Ag-thiol). Importantly, after the 5 weeks of the experiment, Ag speciation no longer depended on the initial speciation. In the presence of either $\mathrm{AgNPs}$ or $\mathrm{AgNO}_{3}$, approximately $40 \%$ of $\mathrm{Ag}$ was in the metallic form, $40 \%$ was complexed to an organic thiol, and $20 \%$ was bound to humic acids. 


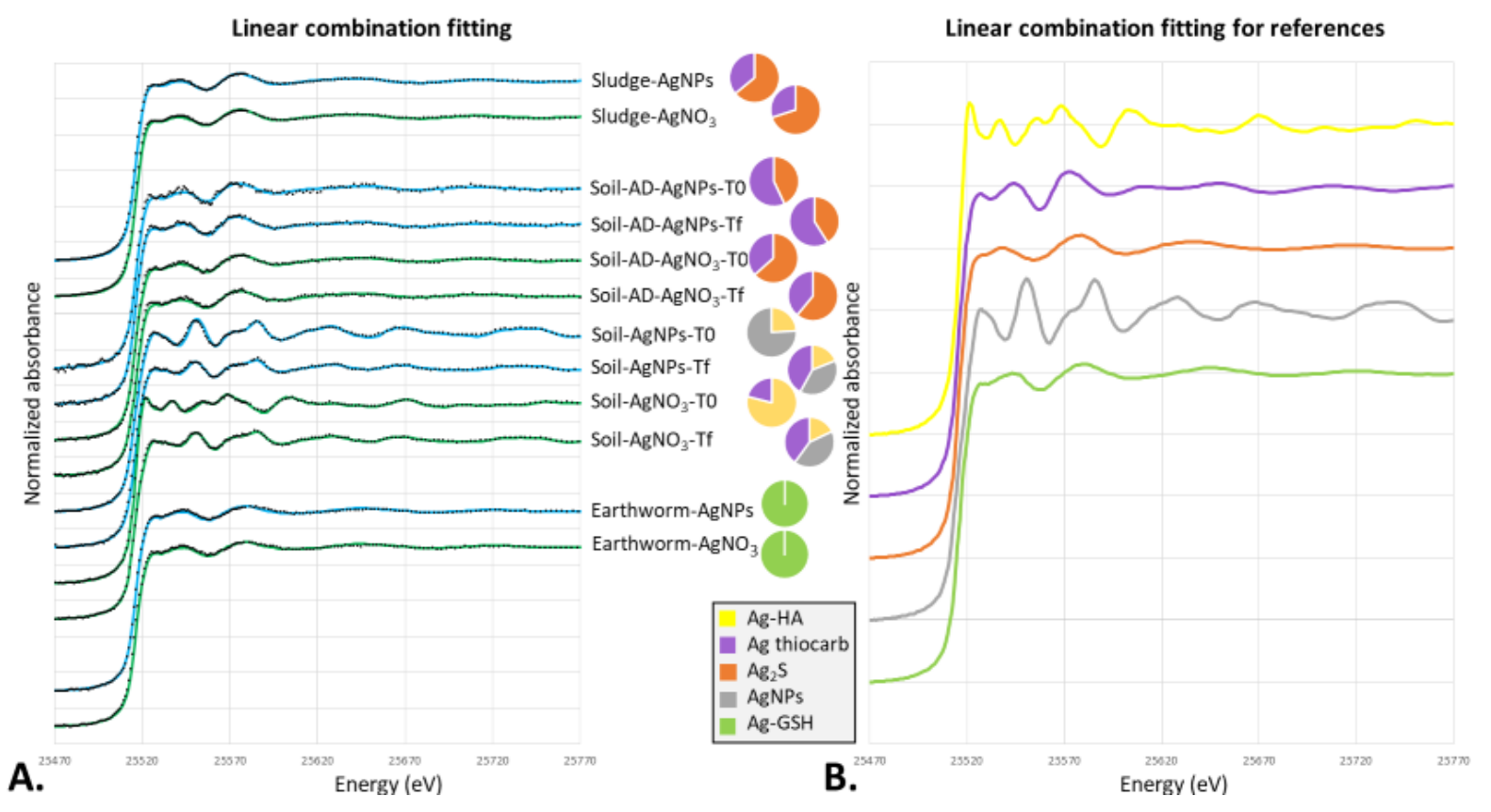

500

501

502

503

504

505

506

507

508

509

510

511

512

513

514

515

516

517 3.2.4. Speciation of Ag bioaccumulated in earthworms containing organic compound.

\section{$A D-A g N P s$ and $A D-\mathrm{AgNO}_{3}$ in soil}

Figure 5: A. Speciation of silver in sewage sludge, soils and mixtures at the beginning (T0) or end (Tf) of the soil incubations and speciation of silver in earthworms: linear combination fitting of XANES spectra is shown on the left (dotted lines correspond to experimental data, and solid colored lines correspond to the fits). Samples (soils, mixtures, sewage sludge or earthworms) from conditions with AgNPs are in blue. Samples from conditions with $\mathrm{AgNO}_{3}$ are in dark green. B. XANES spectra of Ag references. Ag-HA (in yellow) corresponds to Ag complexed with humic acids. AgNPs (in gray) corresponds to the linear combination fitting obtained with a sample of $N M 300 \mathrm{~K} A g N P$ s used for the experiment. $A g_{2} S$ (in orange) corresponds to acanthite, a silver sulfide. Ag-thiocarb (in purple), and Ag-GSH (in light green) corresponds to Ag linked to a thiol-

When spiked in SS prior to addition to soil, the $\mathrm{Ag}$ in the SS was transformed into $\mathrm{Ag}_{2} \mathrm{~S}$ (30-33\%) and Ag bound to a thiol-containing organic compound (67-70\%), regardless of the initial state of the Ag (ionic or NPs) (Figure 5). These two species remained the main species after the addition of SS to the soil, with small variations in the relative proportions of the two species. The speciation of Ag did not change after the 5 weeks of the experiment. 
Investigation of Ag speciation in earthworms was possible only for the soil incubated without SS since the content of bioaccumulated Ag in earthworms exposed to the AD-AgNPs and $\mathrm{AD}-\mathrm{AgNO}_{3}$ microcosms was too low to be analyzed by $\mathrm{X}$-ray absorption spectroscopy (Figure 4). The speciation of Ag bioaccumulated in earthworms was similar regardless of the initial form of $\mathrm{Ag}$ when exposed to $\mathrm{AgNPs}$ or $\mathrm{AgNO}_{3}$. The XANES spectra were identical to those of the Ag-thiol model compound (Figure 5).

\section{Discussion}

Regardless of chemical form, concentration and direct/indirect exposure scenario, Ag had no impact on the life traits of E. fetida relative to the controls. At the investigated doses, Ag did not cause earthworm death and did not affect the reproduction or the biomass of the groups of earthworms. Changes in life traits were observed only for the addition of SS. SS is an important source of organic matter (Suleiman et al., 2017), and thus the food resources available for earthworms were greater in the microcosms supplemented with SS, which allowed the earthworms to gain weight and reproduce. Conversely, the earthworms in the microcosms without SS lost weight and stopped reproducing. These results in conditions without SS show that the worms were stressed, possibly due to a lack of food, so this is important to keep this in mind for the overall results. The absence of addition of food was intentional in order to avoid bringing other contaminants that would prevent comparisons of microcosms with and without SS. Also, adding a large amount of SS, such as in perspective 10, had drastic consequences for earthworm survival. It is known that SS sometimes contains a lot of ammonium, a very toxic compound (Rorat, 2015).

The accumulation of Ag by earthworms did not depend on the Ag concentration in the soil or the initial form of $\mathrm{Ag}$ (NPs or ionic). Direct supply of $\mathrm{Ag}\left(\mathrm{AgNPs}\right.$ or $\left.\mathrm{AgNO}_{3}\right)$ led to significant bioaccumulation of Ag in earthworms (10-20 mg kg-1$)$, whereas the addition of the 
543 two forms of Ag via SS only resulted in slight bioaccumulation ( $\left.2 \mathrm{mg} \mathrm{kg}^{-1} \mathrm{max}\right)$. Thus, $\mathrm{Ag}$ in

544 SS was less bioavailable for earthworms. It is possible that the difference in consumption of the 545 substrate attenuated / exaggerated these differences in bioaccumulation due to the different MO 546 contents between the microcosms with and without SS, however this difference in 547 bioavailability linked to $\mathrm{Ag}$ speciation is a result already known for several animal and plant 548 species (Pradas del Real et al., 2016; Velicogna et al., 2017). Differences in the bioaccumulation 549 of $\mathrm{Cd}, \mathrm{Cu}$, and $\mathrm{Mn}$ in earthworms were observed depending on exposure to Ag. However, the content of metals was dependent on the presence or absence of SS rather than the presence of

551 Ag. SS contains a cocktail of pollutants and metals (including $\mathrm{Cd}, \mathrm{Cu}$ and $\mathrm{Mn}$ ) at high concentrations compared with normal soil.

Regardless of its form and concentration, the presence of Ag did not alter the expression of lysenin $(l y s)$, superoxide dismutase (sod) and cadmium metallothionein $(c d m t)$ genes in earthworms after 5 weeks of exposure. These genes, which are involved in oxidative stress (Choi and Park, 2015), immunity (Hayashi et al., 2015) and defense against toxic metal ions (Hayashi et al., 2013), have been studied previously in the context of Ag. According to the literature, $\mathrm{AgNPs}$ and $\mathrm{AgNO}_{3}$ at high concentration $\left(500 \mathrm{mg} \mathrm{kg}^{-1}\right)$ in natural soil does not affect the expression of the sod gene (Hayashi et al., 2013) while in artificial soil, an overexpression of sod has been observed with $100 \mathrm{mg} \mathrm{kg}^{-1}$ of $\mathrm{AgNO}_{3}$ only (Choi and Park, 2015). In this last cited study, AgNPs did not affect the sod gene expression, even at low concentration (1 to 100 $\mathrm{mg} \mathrm{kg}^{-1}$ ). Only one study showed the effect of $\mathrm{Ag}$ on the lys gene expression with in-vitro conditions. Authors exposed coelomocytes of earthworms to solutions of $\mathrm{AgNPs}$ and $\mathrm{AgNO}_{3}$ at low concentrations during 24 hours and saw a rapid upregulation (measure after $2 \mathrm{~h}$ of exposure) of lys only this AgNPs and a late down-regulation (measure after 8 or $24 \mathrm{~h}$ of exposure) (Hayashi et al., 2015). Cdmt gene has also been studied a little in the context of exposure to Ag. Significant overexpressions of $c d m t$ have been shown in several studies the 
568 first few days (between $1^{\text {st }}$ and $7^{\text {th }}$ day) of exposure with Ag. In artificial and natural soils, $c d m t$

569 seems to be mainly affected by the high Ag contents (Choi and Park, 2015; Hayashi et al., 2013)

570 but in Curieses Silvana et al. (2017) low (0.05 mg kg-1) and high concentrations caused this

571 upregulation. In some cases, when the exposure lasts longer (10 - 14 days), downregulation of

$572 c d m t$ can be observed with low and medium concentrations (0.05 to $\left.50 \mathrm{mg} \mathrm{kg-}^{-1}\right)$ in artificial

573 soil (Bourdineaud et al., 2019; Curieses Silvana et al., 2017). In all these cited studies, the measure of relative expression levels of these 3 genes were measured during the first 2 weeks of exposure. Short-term and long-term defense mechanisms may vary, and it is possible that by observing the expression of the genes after 5 weeks we missed earlier changes in the expression. to organic thiols, consistent with a previous study (Baccaro et al., 2018) and observations in $E$.

579 fetida in a different context of exposure (Courtois et al., 2020). The localization of Ag in organisms, its speciation, and $\mathrm{Cu}-\mathrm{Ag}$ competition for bioaccumulation observed in the latter studies, as well as studies on the role of metallothionein (MT) (Demuynck et al., 2006; Morgan et al., 2004; Sugawara and Sugawara, 1984; Vijver et al., 2004) and changes in the expression 583 of MT-encoding genes in Ag exposure contexts (Curieses Silvana et al., 2017; Hayashi et al., 584 2013), suggest that Ag in earthworms are linked to MT. Regardless of the Ag concentration in soil (perspectives 3, 6, and 10), bioaccumulation in earthworms was similar, suggesting the existence of a regulation mechanism to limit the accumulation and therefore the toxicity of Ag. Such a regulation mechanism in earthworms might involve MT. Thus, by observing all 588 published results, it would seem that the metalloproteins play an early role (first few days / 589 weeks) in the detoxification of $\mathrm{Ag}$ (metallic or ionic) in E. fetida, hence an overexpression of 590 the gene at the start of exposure. Then the expression of the gene returns to normal, probably 591 because other defense mechanisms take over, which would explain that in the study below, at 5925 weeks, no change in gene expression was observed. 
With respect to soil microorganisms, a negative impact of direct exposure to both $\mathrm{Ag}$

594

595

596

597

598

599

600

601

602

603

604

605

606

607

608

609

610

611

612

613

614

615

616

617

forms (NPs and ionic) on potential carbon respiration was observed after 5 weeks of the experiment. However, no effects were detected when Ag was applied via SS. Potential carbon respiration is carried out by numerous groups of optional or obligatory aerobic microorganisms. The absence of an effect on potential carbon respiration does not imply that no microorganism was affected by Ag but instead indicates that the whole community managed to compensate for any negative effects, if any, of Ag on certain groups of microorganisms. The positive effect of the dispersant on potential carbon respiration upon direct addition to the soil can be explained by the fact that the dispersant is a polysorbate, a derivative of sorbitol that is metabolizable by microorganisms. A similar effect was not observed when digested SS with dispersant was added, perhaps because the dispersant had been fully used by the slime microorganisms during anaerobic digestion.

The microbial community composition established using metagenomic tools differed greatly between the microcosms treated with or without SS. It may be explained by changes in microbial composition due to addition of nutrients in the SS. However, 140 microorganisms indicating a SS supply were identified. Most of them are usually found in anaerobic environments and gastrointestinal tract of different animals. This likely indicates the persistence of DNA coming from anaerobic microorganisms present in SS. These microorganisms might be dead or no longer active in soils where conditions are not favorable to them and can hide the weaker effects of Ag supply on the microbial community composition. The microbial composition in the control and dispersant treatments differed from that in the Ag treatments. However, the majority of the variation of microbial composition was due to the addition of SS rather than the addition of Ag. Thus, the differences in response between the two applications modes showed that during SS digestion at the WWTP, Ag underwent strong transformations that led to a total absence of effects on respiration activity and a slight impact on diversity. 
Several authors have reported effects of direct exposure to AgNPs on microbial community composition (Rahmatpour et al., 2017; Samarajeewa et al., 2017), but the design adopted in the present experiment revealed no impact of Ag on the microbial community. The present results are consistent with the few previous studies conducted under similar conditions (Doolette et al., 2016; Durenkamp et al., 2016), which did not observe major effects of low doses of Ag that had undergone fermentation on microbial abundance and communities. However, a short-term effect of Ag cannot be excluded. Indeed, our experiments lasted 35 days, and thus effects occurring within a few days or weeks followed by resilience would not be detected. No microorganisms specifically resistant to Ag were observed, and therefore no microbial indicator of this kind of contamination in soils can be used.

Thus, the lasting effects of introduction of $\mathrm{Ag}$ to the terrestrial environment via SS were slight changes in the soil microbial community and slight but not necessarily significant accumulation of $\mathrm{Ag}$ in earthworms. There was no effect of the form of Ag initially provided or of the $\mathrm{Ag}$ concentration in the microcosms. Thus, the effects of $\mathrm{Ag}$ in SS were strongly attenuated compared with direct introduction of $\mathrm{Ag}$ ( 2 forms $)$ into the soil. These observations can be explained by Ag speciation in soil. During the anaerobic fermentation of SS, Ag underwent chemical transformations. Both $\mathrm{AgNO}_{3}$ and $\mathrm{AgNPs}$ changed in the same manner, and at the end of fermentation, the two forms of Ag were completely sulfided, consistent with previous studies (Levard et al., 2012; Pradas del Real et al., 2016). After mixing in the soil, the Ag remained completely sulfided. These chemical forms were stable and did not evolve much during the 5 weeks of incubation. Silver sulfidation strongly decreases silver toxicity to a variety of (micro-)organisms due to the high chemical stability of the Ag-S species (Levard et al., 2013, 2011; Reinsch et al., 2012). Likewise, when introduced directly into soil, the speciation of $\mathrm{AgNO}_{3}$ and $\mathrm{AgNPs}$ evolved in a similar manner by the end of 5 weeks (with not more than $40 \%$ of Ag bound to sulfur molecules). Thus, in both modes of supply, AgNPs and 
$\mathrm{AgNO}_{3}$ ultimately had the same speciation and therefore similar effects on E. fetida and soil microorganisms. Finally, at low doses, $\mathrm{Ag}$ sulfides are less bioavailable than $\mathrm{Ag}^{+}$or $\mathrm{AgNPs}$ to certain organisms (Courtois et al., 2019), like earthworms (Lahive et al., 2017). The SS initially added with $\mathrm{AgNPs}$ and $\mathrm{AgNO}_{3}$ essentially contained $\mathrm{Ag}$ sulfides at the end of fermentation. Anaerobic treatment of SS thus reduces the toxicity of Ag to organisms.

\section{Conclusion}

In conclusion, after 5 weeks, no strong effect of $\mathrm{Ag}$ on the microbial community and earthworms was observed when Ag was supplied to the soil via a reasonable quantity of SS. Speciation did not differ between $\mathrm{AgNPs}$ and $\mathrm{AgNO}_{3}$ after the major chemical changes that occurred during fermentation. Interestingly, the microbial communities seemed to be highly resistant to Ag species supplied with sewage sludge, and the earthworms seemed to accumulate much less Ag due to reduced bioavailability. The effects of Ag observed in the absence of SS were strongly limited when Ag was previously sulfided due to the digestion of SS.

The results of this study need to be confirmed in other soil types, as microflora are highly site-specific. Other types of SS treatments and shorter time scales should also be investigated to exclude immediate effects (on microorganisms as well as earthworms), and longer time scales should be evaluated to assess the effects of consecutive additions of SS. For earthworms, it would be interesting to study the gene network linked to metallic stress to highlight the genes potentially affected by Ag. Because bioaccumulation was observed, the potential for trophic transfer of Ag should be explored. For microbial communities, processes that are more sensitive than respiration, such as nitrification, could be analyzed. Respiration is performed by a large number of microbial taxa, whereas nitrification is an activity supported by a small number of microbial taxa. Effects of Ag on some of these latter taxa could greatly impact nitrification in soil. 
670 The authors declare no competing financial interest.

671

\section{Acknowledgments}

672 The authors thank Dominique Dubois, Olivier Proux, Régine Leroux, Kerstin Hund-Rinke and

673 Claire Gassie for their technical help in this work and Ana Pradas del Real and Géraldine Sarret 674 for providing part of the XAS spectra for model compounds that were used in this study. We 675 are also grateful to the AME Platforme, the LEM and the Genotoul bioinformatics platform 676 Toulouse Midi-Pyrenees (Bioinfo Genotoul, doi: 10.15454/1.5572369328961167E12) for 677 providing computing and storage resources.

678

\section{Funding}

679 This study was funded by the ANSES in the ETNA ${ }^{2}$ project context and by a grant from the 680 University of Lille and the SMRE doctoral school. 
683

684

685

686

687

688

689

690

691

692

693

694

695

696

697

698

699

700

701

702

703

704

705

706

707

708

709

710

711

712

713

714

715

716

717

718

719

720

721

722

723

724

725

726

727

728
Anderson, J.P.E., Domsch, K.H., 1978. A physiological method for the quantitative measurement of microbial biomass in soils. Soil Biol. Biochem. 10, 215-221. https://doi.org/10.1016/0038-0717(78)90099-8

Anderson, M.J., 2001. A new method for non- parametric multivariate analysis of variance 26, 32-46.

Asadishad, B., Chahal, S., Akbari, A., Cianciarelli, V., Azodi, M., Ghoshal, S., Tufenkji, N., 2018. Amendment of Agricultural Soil with Metal Nanoparticles: Effects on Soil Enzyme Activity and Microbial Community Composition. Environ. Sci. Technol. 52, 1908-1918. https://doi.org/10.1021/acs.est.7b05389

Baccaro, M., Undas, A.K., de Vriendt, J., van den Berg, J.H.J., Peters, R.J.B., van den Brink, N.W., 2018. Ageing, dissolution and biogenic formation of nanoparticles: how do these factors affect the uptake kinetics of silver nanoparticles in earthworms? Environ. Sci. Nano 5, 1107-1116. https://doi.org/10.1039/C7EN01212H

Bernard, F., Brulle, F., Douay, F., Lemière, S., Demuynck, S., Vandenbulcke, F., 2010. Metallic trace element body burdens and gene expression analysis of biomarker candidates in Eisenia fetida, using an "exposure/depuration" experimental scheme with field soils. Ecotoxicol. Environ. Saf. 73, 1034-1045. https://doi.org/10.1016/j.ecoenv.2010.01.010

Bernard, F., Brulle, F., Dumez, S., Lemiere, S., Platel, A., Nesslany, F., Cuny, D., Deram, A., Vandenbulcke, F., 2015. Antioxidant responses of Annelids, Brassicaceae and Fabaceae to pollutants: A review. Ecotoxicol. Environ. Saf. 114, 273-303. https://doi.org/10.1016/j.ecoenv.2014.04.024

Bokulich, N.A., Subramanian, S., Faith, J.J., Gevers, D., Gordon, J.I., Knight, R., Mills, D.A., Caporaso, J.G., 2013. Quality-filtering vastly improves diversity estimates from Illumina amplicon sequencing. Nat. Methods 10, 57-59. https://doi.org/10.1038/nmeth.2276

Bourdineaud, J.-P., Štambuk, A., Šrut, M., Radić Brkanac, S., Ivanković, D., Lisjak, D., Sauerborn Klobučar, R., Dragun, Z., Bačić, N., Klobučar, G.I.V., 2019. Gold and silver nanoparticles effects to the earthworm Eisenia fetida - the importance of tissue over soil concentrations. Drug Chem. Toxicol. 1-18. https://doi.org/10.1080/01480545.2019.1567757

Brulle, F., Lemière, S., Waterlot, C., Douay, F., Vandenbulcke, F., 2011. Gene expression analysis of 4 biomarker candidates in Eisenia fetida exposed to an environmental metallic trace elements gradient: A microcosm study. Sci. Total Environ. 409, 54705482. https://doi.org/10.1016/j.scitotenv.2011.08.040

Brulle, F., Mitta, G., Cocquerelle, C., Vieau, D., Lemière, S., Leprêtre, A., Vandenbulcke, F., 2006. Cloning and Real-Time PCR Testing of 14 Potential Biomarkers in Eisenia fetida Following Cadmium Exposure. Environ. Sci. Technol. 40, 2844-2850. https://doi.org/10.1021/es052299x

Carbonell, G., Pro, J., Gómez, N., Babín, M.M., Fernández, C., Alonso, E., Tarazona, J.V., 2009. Sewage sludge applied to agricultural soil: Ecotoxicological effects on representative soil organisms. Ecotoxicol. Environ. Saf. 72, 1309-1319. https://doi.org/10.1016/j.ecoenv.2009.01.007

Choi, J.S., Park, J.-W., 2015. Molecular characterization and toxicological effects of citratecoated silver nanoparticles in a terrestrial invertebrate, the earthworm (Eisenia fetida). Mol. Cell. Toxicol. 11, 423-431. https://doi.org/10.1007/s13273-015-0045-z 
Circular DE / GE $n{ }^{\circ} 357$ of 03/16/99, 1999. Circular DE / GE ${ }^{\circ} 357$ of 03/16/99 relating to the regulations relating to the spreading of sludge from urban wastewater treatment plants.

Courtois, P., Rorat, A., Lemiere, S., Guyoneaud, R., Attard, E., Levard, C., Vandenbulcke, F., 2019. Ecotoxicology of silver nanoparticles and their derivatives introduced in soil with or without sewage sludge: A review of effects on microorganisms, plants and animals. Environ. Pollut. 253, 578-598. https://doi.org/10.1016/j.envpol.2019.07.053

Courtois, P., Rorat, A., Lemiere, S., Levard, C., Chaurand, P., Grobelak, A., Lors, C., Vandenbulcke, F., 2020. Accumulation, speciation and localization of silver nanoparticles in the earthworm Eisenia fetida. Environ. Sci. Pollut. Res. Int. https://doi.org/10.1007/s11356-020-08548-z

Curieses Silvana, P., García-Velasco, N., Urionabarrenetxea, E., Elena, S.M., Bilbao, E., Di Marzio Walter, D., Soto, M., 2017. Responses to silver nanoparticles and silver nitrate in a battery of biomarkers measured in coelomocytes and in target tissues of Eisenia fetida earthworms. Ecotoxicol. Environ. Saf. 141, 57-63. https://doi.org/10.1016/j.ecoenv.2017.03.008

De Cáceres, M., Legendre, P., Moretti, M., 2010. Improving indicator species analysis by combining groups of sites. Oikos 119, 1674-1684. https://doi.org/10.1111/j.16000706.2010.18334.x

Demuynck, S., Grumiaux, F., Mottier, V., Schikorski, D., Lemière, S., Leprêtre, A., 2006. Metallothionein response following cadmium exposure in the oligochaete Eisenia fetida. Comp. Biochem. Physiol. Toxicol. Pharmacol. CBP 144, 34-46. https://doi.org/10.1016/j.cbpc.2006.05.004

Diez-Ortiz, M., Lahive, E., Kille, P., Powell, K., Morgan, A.J., Jurkschat, K., Van Gestel, C.A.M., Mosselmans, J.F.W., Svendsen, C., Spurgeon, D.J., 2015. Uptake routes and toxicokinetics of silver nanoparticles and silver ions in the earthworm Lumbricus rubellus. Environ. Toxicol. Chem. 34, 2263-2270. https://doi.org/10.1002/etc.3036

Diogène, J., Dufour, M., Poirier, G.G., Nadeau, D., 1997. Extrusion of earthworm coelomocytes: comparison of the cell populations recovered from the species Lumbricus terrestris, Eisenia fetida and Octolasion tyrtaeum. Lab. Anim. 31, 326-336. https://doi.org/10.1258/002367797780596068

Doolette, C.L., Gupta, V.V.S.R., Lu, Y., Payne, J.L., Batstone, D.J., Kirby, J.K., Navarro, D.A., McLaughlin, M.J., 2016. Quantifying the Sensitivity of Soil Microbial Communities to Silver Sulfide Nanoparticles Using Metagenome Sequencing. PLOS ONE 11, e0161979. https://doi.org/10.1371/journal.pone.0161979

DRAAF, N.-P. de C., 2013. Inventaire, Gestion et Conservation des Sols dans le Nord - Pas de Clais [WWW Document]. URL http://draaf.hauts-defrance.agriculture.gouv.fr/IMG/pdf/Demarche_IGCS_dans_le_NordPas_de_Calais_v2013-04-06_cle014cb8.pdf (accessed 1.8.20).

Dufrene, M., Legendre, P., 1997. Species Assemblages and Indicator Species: The Need for a Flexible Asymmetrical Approach. Ecol. Monogr. 67, 345-366. https://doi.org/10.2307/2963459

Durenkamp, M., Pawlett, M., Ritz, K., Harris, J.A., Neal, A.L., McGrath, S.P., 2016. Nanoparticles within WWTP sludges have minimal impact on leachate quality and soil microbial community structure and function. Environ. Pollut. 211, 399-405. https://doi.org/10.1016/j.envpol.2015.12.063

Escudié, F., Auer, L., Bernard, M., Mariadassou, M., Cauquil, L., Vidal, K., Maman, S., Hernandez-Raquet, G., Combes, S., Pascal, G., 2018. FROGS: Find, Rapidly, OTUs with Galaxy Solution. Bioinforma. Oxf. Engl. 34, 1287-1294. https://doi.org/10.1093/bioinformatics/btx791 
European commission, 2017. REPORT FROM THE COMMISSION TO THE EUROPEAN PARLIAMENT, THE COUNCIL, THE EUROPEAN ECONOMIC AND SOCIAL COMMITTEE AND THE COMMITTEE OF THE REGIONS.

Eyambe, G.S., Goven, A.J., Fitzpatrick, L.C., Venables, B.J., Cooper, E.L., 1991. A noninvasive technique for sequential collection of earthworm (Lumbricus terrestris) leukocytes during subchronic immunotoxicity studies. Lab. Anim. 25, 61-67. https://doi.org/10.1258/002367791780808095

Gomes, S.I.L., Hansen, D., Scott-Fordsmand, J.J., Amorim, M.J.B., 2015. Effects of silver nanoparticles to soil invertebrates: Oxidative stress biomarkers in Eisenia fetida. Environ. Pollut. 199, 49-55. https://doi.org/10.1016/j.envpol.2015.01.012

Grosser, A., 2017. The influence of decreased hydraulic retention time on the performance and stability of co-digestion of sewage sludge with grease trap sludge and organic fraction of municipal waste. J. Environ. Manage., Environmental management as a pillar for sustainable development 203, 1143-1157. https://doi.org/10.1016/j.jenvman.2017.04.085

Hammer, O., Harper, D.A.T., Ryan, P.D., 2001. PAST: Paleontological Statistics Software Package for Education and Data Analysis 9.

Hänsch, M., Emmerling, C., 2010. Effects of silver nanoparticles on the microbiota and enzyme activity in soil. J. Plant Nutr. Soil Sci. 173, 554-558. https://doi.org/10.1002/jpln.200900358

Hayashi, Y., Heckmann, L.-H., Simonsen, V., Scott-Fordsmand, J.J., 2013. Time-course profiling of molecular stress responses to silver nanoparticles in the earthworm Eisenia fetida. Ecotoxicol. Environ. Saf. 98, 219-226. https://doi.org/10.1016/j.ecoenv.2013.08.017

Hayashi, Y., Miclaus, T., Engelmann, P., Autrup, H., Sutherland, D.S., Scott-Fordsmand, J.J., 2015. Nanosilver pathophysiology in earthworms: Transcriptional profiling of secretory proteins and the implication for the protein corona. Nanotoxicology 10, 303311. https://doi.org/10.3109/17435390.2015.1054909

He, S., Feng, Youzhi, Ni, J., Sun, Y., Xue, L., Feng, Yanfang, Yu, Y., Lin, X., Yang, L., 2016. Different responses of soil microbial metabolic activity to silver and iron oxide nanoparticles. Chemosphere 147, 195-202. https://doi.org/10.1016/j.chemosphere.2015.12.055

Höckner, M., Dallinger, R., Stürzenbaum, S.R., 2011. Nematode and snail metallothioneins. JBIC J. Biol. Inorg. Chem. 16, 1057. https://doi.org/10.1007/s00775-011-0826-3

Homa, J., Rorat, A., Kruk, J., Cocquerelle, C., Plytycz, B., Vandenbulcke, F., 2015. Dermal exposure of Eisenia andrei earthworms: Effects of heavy metals on metallothionein and phytochelatin synthase gene expressions in coelomocytes. Environ. Toxicol. Chem. 34, 1397-1404. https://doi.org/10.1002/etc.2944

Kaegi, R., Voegelin, A., Sinnet, B., Zuleeg, S., Hagendorfer, H., Burkhardt, M., Siegrist, H., 2011. Behavior of Metallic Silver Nanoparticles in a Pilot Wastewater Treatment Plant. Environ. Sci. Technol. 45, 3902-3908. https://doi.org/10.1021/es1041892

Klein, C.L., Stahlmecke, B., Romazanov, J., Kuhlbusch, T.A.J., Van Doren, E., De Temmerman, P.-J., Mast, J., Wick, P., Krug, H., Locoro, G., Hund-Rinke, K., Kördel, W., Friedrichs, S., Maier, G., Werner, J., Linsinger, T., Gawlik, B.M., Comero, S., Institute for Health and Consumer Protection, European Commission, Joint Research Centre, Institute for Environment and Sustainability, Institute for Reference Materials and Measurements, 2011. NM-Series of representative manufactured nanomaterials: NM-300 silver characterisation, stability, homogeneity. Publications Office, Luxembourg. 
Kumar, N., Palmer, G.R., Shah, V., Walker, V.K., 2014. The Effect of Silver Nanoparticles on Seasonal Change in Arctic Tundra Bacterial and Fungal Assemblages. PLoS ONE 9, e99953. https://doi.org/10.1371/journal.pone.0099953

Lahive, E., Matzke, M., Durenkamp, M., Lawlor, A.J., Thacker, S.A., Pereira, M.G., Spurgeon, D.J., Unrine, J.M., Svendsen, C., Lofts, S., 2017. Sewage sludge treated with metal nanomaterials inhibits earthworm reproduction more strongly than sludge treated with metal metals in bulk/salt forms. Environ. Sci. Nano 4, 78-88. https://doi.org/10.1039/C6EN00280C

Levard, C., Hotze, E.M., Colman, B.P., Dale, A.L., Truong, L., Yang, X.Y., Bone, A.J., Brown, G.E., Tanguay, R.L., Di Giulio, R.T., Bernhardt, E.S., Meyer, J.N., Wiesner, M.R., Lowry, G.V., 2013. Sulfidation of Silver Nanoparticles: Natural Antidote to Their Toxicity. Environ. Sci. Technol. 47, 13440-13448. https://doi.org/10.1021/es403527n

Levard, C., Hotze, E.M., Lowry, G.V., Brown, G.E., 2012. Environmental Transformations of Silver Nanoparticles: Impact on Stability and Toxicity. Environ. Sci. Technol. 46, 6900-6914. https://doi.org/10.1021/es2037405

Levard, C., Reinsch, B.C., Michel, F.M., Oumahi, C., Lowry, G.V., Brown, G.E., 2011. Sulfidation Processes of PVP-Coated Silver Nanoparticles in Aqueous Solution: Impact on Dissolution Rate. Environ. Sci. Technol. 45, 5260-5266. https://doi.org/10.1021/es2007758

Liu, G., Zhang, M., Jin, Y., Fan, X., Xu, J., Zhu, Y., Fu, Z., Pan, X., Qian, H., 2017. The Effects of Low Concentrations of Silver Nanoparticles on Wheat Growth, Seed Quality, and Soil Microbial Communities. Water. Air. Soil Pollut. 228, 348. https://doi.org/10.1007/s11270-017-3523-1

Livak, K.J., Schmittgen, T.D., 2001. Analysis of Relative Gene Expression Data Using RealTime Quantitative PCR and the 2- $\Delta \Delta \mathrm{CT}$ Method. Methods 25, 402-408. https://doi.org/10.1006/meth.2001.1262

Ma, R., Levard, C., Judy, J.D., Unrine, J.M., Durenkamp, M., Martin, B., Jefferson, B., Lowry, G.V., 2014. Fate of Zinc Oxide and Silver Nanoparticles in a Pilot Wastewater Treatment Plant and in Processed Biosolids. Environ. Sci. Technol. 48, 104-112. https://doi.org/10.1021/es403646x

Mahé, F., Rognes, T., Quince, C., Vargas, C. de, Dunthorn, M., 2014. Swarm: robust and fast clustering method for amplicon-based studies. PeerJ 2, e593. https://doi.org/10.7717/peerj.593

McGee, C.F., Storey, S., Clipson, N., Doyle, E., 2017. Soil microbial community responses to contamination with silver, aluminium oxide and silicon dioxide nanoparticles. Ecotoxicology 26, 449-458. https://doi.org/10.1007/s10646-017-1776-5

McGillicuddy, E., Murray, I., Kavanagh, S., Morrison, L., Fogarty, A., Cormican, M., Dockery, P., Prendergast, M., Rowan, N., Morris, D., 2017. Silver nanoparticles in the environment: Sources, detection and ecotoxicology. Sci. Total Environ. 575, 231-246. https://doi.org/10.1016/j.scitotenv.2016.10.041

Mendes, L.A., Maria, V.L., Scott-Fordsmand, J.J., Amorim, M.J.B., 2015. Ag Nanoparticles (Ag NM300K) in the Terrestrial Environment: Effects at Population and Cellular Level in Folsomia candida (Collembola). Int. J. Environ. Res. Public. Health 12, 12530-12542. https://doi.org/10.3390/ijerph121012530

Morgan, A.J., Stürzenbaum, S.R., Winters, C., Grime, G.W., Aziz, N.A.A., Kille, P., 2004. Differential metallothionein expression in earthworm (Lumbricus rubellus) tissues. Ecotoxicol. Environ. Saf. 57, 11-19. https://doi.org/10.1016/j.ecoenv.2003.08.022 Novo, M., Lahive, E., Díez-Ortiz, M., Matzke, M., Morgan, A.J., Spurgeon, D.J., Svendsen, C., Kille, P., 2015. Different routes, same pathways: Molecular mechanisms under 
silver ion and nanoparticle exposures in the soil sentinel Eisenia fetida. Environ. Pollut. 205, 385-393. https://doi.org/10.1016/j.envpol.2015.07.010

Pradas del Real, A.E., Castillo-Michel, H., Kaegi, R., Sinnet, B., Magnin, V., Findling, N., Villanova, J., Carrière, M., Santaella, C., Fernández-Martínez, A., Levard, C., Sarret, G., 2016. Fate of Ag-NPs in Sewage Sludge after Application on Agricultural Soils. Environ. Sci. Technol. 50, 1759-1768. https://doi.org/10.1021/acs.est.5b04550

Proux, O., Biquard, X., Lahera, E., Menthonnex, J.-J., Prat, A., Ulrich, O., Soldo, Y., Trévisson, P., Kapoujyan, G., Perroux, G., Taunier, P., Grand, D., Jeantet, P., Deléglise, M., Roux, J.-P., Hazemann, J.-L., 2005. FAME : A new beamline for X-ray absorption investigations of very-diluted systems of environmental, material and biological interests. Phys. Scr. 115, 970-973. https://doi.org/10.1238/Physica.Topical.115a00970

Quast, C., Pruesse, E., Yilmaz, P., Gerken, J., Schweer, T., Yarza, P., Peplies, J., Glöckner, F.O., 2013. The SILVA ribosomal RNA gene database project: improved data processing and web-based tools. Nucleic Acids Res. 41, D590-D596. https://doi.org/10.1093/nar/gks1219

R Core Team, 2008. R: A language and environment for statistical computing. R Foundation for Statistical Computing, Vienna, Austria. URL https://www.R-project.org/.

Rahmatpour, S., Shirvani, M., Mosaddeghi, M.R., Nourbakhsh, F., Bazarganipour, M., 2017. Dose-response effects of silver nanoparticles and silver nitrate on microbial and enzyme activities in calcareous soils. Geoderma 285, 313-322. https://doi.org/10.1016/j.geoderma.2016.10.006

Ravel, B., Newville, M., 2005. ATHENA, ARTEMIS, HEPHAESTUS: data analysis for Xray absorption spectroscopy using IFEFFIT. J. Synchrotron Radiat. 12, 537-541. https://doi.org/10.1107/S0909049505012719

Reinsch, B.C., Levard, C., Li, Z., Ma, R., Wise, A., Gregory, K.B., Brown, G.E., Lowry, G.V., 2012. Sulfidation of silver nanoparticles decreases Escherichia coli growth inhibition. Environ. Sci. Technol. 46, 6992-7000. https://doi.org/10.1021/es203732x

Rognes, T., Flouri, T., Nichols, B., Quince, C., Mahé, F., 2016. VSEARCH: a versatile open source tool for metagenomics. PeerJ 4, e2584. https://doi.org/10.7717/peerj.2584

Rorat, A., 2015. Assessment of the vermicomposting process applied to sewage sludge by monitoring of the compost quality and immune responses ofthree earthworm species: Eisenia fetida, Eisenia andrei and Dendrobaena veneta.

Rorat, A., Vandenbulcke, F., Gałuszka, A., Klimek, B., Plytycz, B., 2017. Protective role of metallothionein during regeneration in Eisenia andrei exposed to cadmium. Comp. Biochem. Physiol. Part C Toxicol. Pharmacol. 203, 39-50. https://doi.org/10.1016/j.cbpc.2017.10.002

Samarajeewa, A.D., Velicogna, J.R., Princz, J.I., Subasinghe, R.M., Scroggins, R.P., Beaudette, L.A., 2017. Effect of silver nano-particles on soil microbial growth, activity and community diversity in a sandy loam soil. Environ. Pollut. 220, 504-513. https://doi.org/10.1016/j.envpol.2016.09.094

Schlich, K., Klawonn, T., Terytze, K., Hund-Rinke, K., 2013. Effects of silver nanoparticles and silver nitrate in the earthworm reproduction test. Environ. Toxicol. Chem. 32, 181-188. https://doi.org/10.1002/etc. 2030

Shoults-Wilson, W.A., Reinsch, B.C., Tsyusko, O.V., Bertsch, P.M., Lowry, G.V., Unrine, J.M., 2010. Effect of silver nanoparticle surface coating on bioaccumulation and reproductive toxicity in earthworms ( Eisenia fetida). Nanotoxicology 5, 432-444. https://doi.org/10.3109/17435390.2010.537382

Sillen, W.M.A., Thijs, S., Abbamondi, G.R., Janssen, J., Weyens, N., White, J.C., Vangronsveld, J., 2015. Effects of silver nanoparticles on soil microorganisms and 
maize biomass are linked in the rhizosphere. Soil Biol. Biochem. 91, 14-22. https://doi.org/10.1016/j.soilbio.2015.08.019

Sugawara, N., Sugawara, C., 1984. Comparative study of effect of acute administration of cadmium and silver on ceruloplasmin and metallothionein: Involvement of disposition of copper, iron, and zinc. Environ. Res. 35, 507-515. https://doi.org/10.1016/00139351(84)90157-9

Suleiman, H., Rorat, A., Grobelak, A., Grosser, A., Milczarek, M., Płytycz, B., Kacprzak, M., Vandenbulcke, F., 2017. Determination of the performance of vermicomposting process applied to sewage sludge by monitoring of the compost quality and immune responses in three earthworm species: Eisenia fetida, Eisenia andrei and Dendrobaena veneta. Bioresour. Technol. 241, 103-112. https://doi.org/10.1016/j.biortech.2017.05.104

Tiede, K., Boxall, A.B.A., Wang, X., Gore, D., Tiede, D., Baxter, M., David, H., Tear, S.P., Lewis, J., 2010. Application of hydrodynamic chromatography-ICP-MS to investigate the fate of silver nanoparticles in activated sludge. J. Anal. At. Spectrom. 25, 1149. https://doi.org/10.1039/b926029c

Vance, M.E., Kuiken, T., Vejerano, E.P., McGinnis, S.P., Hochella, M.F., Rejeski, D., Hull, M.S., 2015. Nanotechnology in the real world: Redeveloping the nanomaterial consumer products inventory. Beilstein J. Nanotechnol. 6, 1769-1780. https://doi.org/10.3762/bjnano.6.181

Velicogna, J.R., Schwertfeger, D.M., Jesmer, A.H., Scroggins, R.P., Princz, J.I., 2017. The bioaccumulation of silver in Eisenia andrei exposed to silver nanoparticles and silver nitrate in soil. NanoImpact 6, 11-18. https://doi.org/10.1016/j.impact.2017.03.001

Vijver, M.G., Van Gestel, C.A.M., Lanno, R.P., Van Straalen, N.M., Peijnenburg, W.J.G.M., 2004. Internal metal sequestration and its ecotoxicological relevance: a review. Environ. Sci. Technol. 38, 4705-4712. https://doi.org/10.1021/es040354g Yang, X., Gondikas, A.P., Marinakos, S.M., Auffan, M., Liu, J., Hsu-Kim, H., Meyer, J.N., 2012. Mechanism of Silver Nanoparticle Toxicity Is Dependent on Dissolved Silver and Surface Coating in Caenorhabditis elegans. Environ. Sci. Technol. 46, 11191127. https://doi.org/10.1021/es202417t 
Object: Submission Chemosphere

Dear Editor,

Please find attached the manuscript entitled «Medium-term effects of Ag is supplied directly or via sewage sludge to an agricultural soil on Eisenia fetida earthworm and soil microbial communities») for consideration to publication as a Research article in Chemosphere. Information on the co-authors can be found at the end of this letter.

This article focus on the effects caused by silver contamination of agricultural soil due to human practices. Indeed, silver nanoparticles (AgNPs) used in consumer products end especially in soils via spreading of biosolids since wastewater treatment retains $\mathrm{Ag}$ in sewage sludge. Ecotoxicological assessment is very important since Ag can impact terrestrial environment and create ecological and economic problems. In this study, we assessed the effects of direct exposure to AgNPs or indirect exposure via sewage sludge contaminated with AgNPs on the earthworm test species Eisenia fetida and soil microbial communities. We have carried out various and numerous physico-chemical (speciation, dosages) and biological (life traits, gene expression, potential carbon respiration, microbial diversity) analysis.

We believe that this article would have a perfect place in Chemosphere journal because fit perfectly to your topics: emerging contaminant, environmental fate with bioaccumulation, speciation of contaminant, adverse effects of contaminant in terrestrial organisms and effects of nanoparticles in the environment. In addition, it could have a wide audience interested by environmental subjects. Indeed, this study is the only one which allows a global vision of the effects of the silver brought by sewage sludge in agricultural soil, bringing together biological, microbiological and chemical points of view, while respecting realistic contamination conditions. Here, the multidisciplinarity does not prevent from showing complex and in-depth results in each area. In addition, we believe that this article will encourage new research since "realistic" studies in this area are largely missing. (see our recent Review published in Environmental Pollution by Courtois et al., 2019 ; https://doi.org/10.1016/j.envpol.2019.07.053).

Please, find below a list of names and addresses of referees familiar with this topic:

-1/ Benjamin P. Colman,

Duke university, Durham, United States of America

E-mail: benjamin.colman@duke.edu

-2/ Christoph Emmerling 
Department of Soil Science, Faculty of Regional and Environmental Science, University of Trier, Campus II, 54286, Trier, Germany

emmerling@uni-trier.de

-3) Barbara Plytycz

Department of Evolutionary Immunobiology

Institute of Zoology, Jagiellonian University

barbara.plytycz@uj.edu.pl

-4) Ewa Neczaj

Czestochowa University of Technology, Poland

Institute of Environmental Engineering

enecz@,is.pcz.czest.pl

-5) Cornelis Kees van Gestel

Faculty of Science, Animal Ecology

Vrije Unisersiteit Amsterdam

kees.van.gestel@vu.nl

-6) Susana Loureiro

University of Aveiro, Department of Biology and CESAM

sloureiro@ua.pt

We have carefully read the author guidelines and wrote this manuscript accordingly to meet the requirements of Chemosphere. Also, the paper has been reread and validated (spell and grammar) by a certified native English speaker. All co-authors have contributed and agree with its content. None of co-authors have any conflicts of interest with regards to this study and there is no financial interest to report. Also, we confirm that all data, figures, pictures and images in the graphical abstract and the manuscript were created by the co-authors. Finally, we certify that you are currently the only journal to which we are submitting this article, so it is not being reviewed in other journals. Part of the results were presented at conferences, with posters and oral platform, which do not spoil the originality of these data and discussion.

We thank you for taking time to consider this study and we look forward to hearing from you in the earliest convenience.

Yours sincerely,

Pauline COURTOIS

Franck VANDENBULKE 


\section{Information on co-authors :}

Pauline Courtois ${ }^{1}$ : pauline.courtois@univ-lille.fr (corresponding author)

Agnieszka Rorat ${ }^{1}$ : agnieszka.rorat@univ-lille.fr

Sébastien Lemiere ${ }^{1}$ : sebastien.lemiere@univ-lille.fr

Rémy Guyoneaud ${ }^{2}$ : remy.guyoneaud@univ-pau.fr

Eléonore Attard ${ }^{2}$ : eleonore.attard@univ-pau.fr

Manon Longepierre ${ }^{2}$ : manon.longepierre@usys.ethz.ch

François Rigal $^{3}$ : francois.rigal@univ-pau.fr

Clément Levard ${ }^{4}$ : levard@cerege.fr

Perrine Chaurand ${ }^{4}$ : chaurand@cerege.fr

Anna Grosser ${ }^{5}$ : agrosser@is.pcz.czest.pl

Anna Grobelak ${ }^{5}$ : anna.grobelak@pcz.pl

Malgorzata Kacprzak ${ }^{5}$ : mkacprzak@is.pcz.czest.pl

Christine Lors ${ }^{1}$ : christine.lors@imt-lille-douai.fr

Agnès Richaume ${ }^{6}$ : agnes.richaume-jolion@univ-lyon1.fr

Franck Vandenbulcke' : franck.vandenbulcke@univ-lille.fr

\section{Affiliations:}

1 Univ. Lille, IMT Lille Douai, Univ. Artois, Yncrea Hauts-de-France, ULR4515 - LGCgE, Laboratoire de Génie Civil et géo-Environnement, F-59000 Lille, France

2 Université de Pau et des Pays de l'Adour, E2S UPPA, CNRS, UMR IPREM 5254, Environmental Microbiology, 64000, Pau, France

3 Azorean Biodiversity Group, Centre for Ecology, Evolution and Environmental Changes (CE3C), Departamento de Ciências Agráriase Engenharia do Ambiente, Universidade dos Açores, PT-9700-042 Angra do Heroísmo, Açores, Portugal

4 Aix Marseille Univ, CNRS, IRD, INRAE, Coll France, CEREGE, Aix-en-Provence, France

5 Częstochowa University of Technology, Faculty of Infrastructure and Environment, Czestochowa, Poland

6 LEM - Laboratoire d'Ecologie Microbienne - UMR 5557 - 69622 Villeurbanne, France 

0

Medium-term effects of $\mathbf{A g}$ is supplied directly or via sewage sludge to an agricultural

\section{soil on Eisenia fetida earthworm and soil microbial communities.}

Pauline Courtois $^{1^{*}}$, Agnieszka Rorat ${ }^{1}$, Sébastien Lemiere ${ }^{1}$, Rémy Guyoneaud ${ }^{2}$, Eléonore Attard $^{2}$, Manon Longepierre ${ }^{2}$, François Rigal $^{3}$, Clément Levard $^{4}$, Perrine Chaurand ${ }^{4}$, Anna

Grosser $^{5}$, Anna Grobelak ${ }^{5}$, Malgorzata Kacprzak ${ }^{5}$, Christine Lors ${ }^{1}$, Agnès Richaume ${ }^{6}$ and Franck Vandenbulcke ${ }^{1}$ 8

${ }^{1}$ Univ. Lille, IMT Lille Douai, Univ. Artois, Yncrea Hauts-de-France, ULR4515 - LGCgE, Laboratoire de Génie Civil et géo-Environnement, F-59000 Lille, France

2 Université de Pau et des Pays de l'Adour, E2S UPPA, CNRS, UMR IPREM 5254, Environmental Microbiology, 64000, Pau, France

${ }^{3}$ Azorean Biodiversity Group, Centre for Ecology, Evolution and Environmental Changes (CE3C), Departamento de Ciências Agráriase Engenharia do Ambiente, Universidade dos Açores, PT-9700-042 Angra do Heroísmo, Açores, Portugal

${ }^{4}$ Aix Marseille Univ, CNRS, IRD, INRAE, Coll France, CEREGE, Aix-en-Provence, France

5 Częstochowa University of Technology, Faculty of Infrastructure and Environment, Czestochowa, Poland

${ }^{6}$ LEM - Laboratoire d'Ecologie Microbienne - UMR 5557 - 69622 Villeurbanne, France

*Address correspondence to: Pauline Courtois

e-mail: pauline.courtois@univ-lille.fr

Université de Lille, Sciences et Technologies

Laboratoire de Génie Civil et géo-Environnement, LGCgE EA4515

Cité Scientifique, Bât. SN3 - F-59655 Villeneuve d'Ascq 


\section{Medium-term effects of $\mathrm{Ag}$ is supplied directly or via sewage sludge to an agricultural soil on Eisenia fetida earthworm and soil microbial communities.}

Pauline Courtois $^{1^{*}}$, Agnieszka Rorat ${ }^{1}$, Sébastien Lemiere ${ }^{1}$, Rémy Guyoneaud ${ }^{2}$, Eléonore Attard $^{2}$, Manon Longepierre ${ }^{2}$, François Rigal ${ }^{3}$, Clément Levard ${ }^{4}$, Perrine Chaurand ${ }^{4}$, Anna Grosser $^{5}$, Anna Grobelak ${ }^{5}$, Malgorzata Kacprzak ${ }^{5}$, Christine Lors ${ }^{1}$, Agnès Richaume ${ }^{6}$ and Franck Vandenbulcke ${ }^{1}$

Highlights:

- Ag is brought to the agricultural soil from spreading of contaminated sewage sludge

- Eisenia fetida bioaccumulate few amount of Ag in realistic scenario of exposure

- In realistic scenario, Ag change a little the diversity of soil microbial communities

- Speciation of Ag in sewage sludge causes less effect than nanoparticulate metallic Ag 
Object: Submission Chemosphere

Title: Medium-term effects of $\mathrm{Ag}$ is supplied directly or via sewage sludge to an agricultural soil on Eisenia fetida earthworm and soil microbial communities

None of co-authors have any conflicts of interest with regards to this study and there is no financial interest to report. 
Medium-term effects of $\mathbf{A g}$ is supplied directly or via sewage sludge to an agricultural soil on Eisenia fetida earthworm and soil microbial communities.

Pauline Courtois ${ }^{1 *}$, Agnieszka Rorat ${ }^{1}$, Sébastien Lemiere ${ }^{1}$, Rémy Guyoneaud ${ }^{2}$, Eléonore Attard $^{2}$, Manon Longepierre ${ }^{2}$, François Rigal ${ }^{3}$, Clément Levard ${ }^{4}$, Perrine Chaurand ${ }^{4}$, Anna Grosser $^{5}$, Anna Grobelak ${ }^{5}$, Malgorzata Kacprzak ${ }^{5}$, Christine Lors ${ }^{1}$, Agnès Richaume ${ }^{6}$ and Franck Vandenbulcke ${ }^{1}$

\section{$\underline{\text { Abstract }}$}

The widespread use of silver nanoparticles (AgNPs) in consumer products that release Ag throughout their life cycle has raised potential environmental concerns. AgNPs primarily accumulate in soil through the spreading of sewage sludge (SS). In this study, the effects of direct exposure to AgNPs or indirect exposure via SS contaminated with AgNPs on the earthworm Eisenia fetida and soil microbial communities were compared, through 3 scenarios offering increasing exposure concentrations. The effects of Ag speciation were analyzed by spiking SS with AgNPs or $\mathrm{AgNO}_{3}$ before application to soil. SS treatment strongly impacted $\mathrm{Ag}$ speciation due to the formation of $\mathrm{Ag}_{2} \mathrm{~S}$ species that remained sulfided after mixing in the soil. The life traits and expression of lysenin, superoxide dismutase, cd-metallothionein genes in earthworms were not impacted by Ag after 5 weeks of exposure, but direct exposure to $\mathrm{Ag}$ without SS led to bioaccumulation of Ag, suggesting transfer in the food chain. Ag exposure led to a decrease in potential carbon respiration only when directly added to the soil. The addition of SS had a greater effect on soil microbial diversity than the form of Ag, and the formation of $\mathrm{Ag}$ sulfides in SS reduced the impact of AgNPs on E. fetida and soil microorganisms compared with direct addition.

Keywords: Silver nanoparticles, silver sulfide, ecotoxicology, earthworms, microorganisms, speciation 
Percentage of biomass won or lost (\%)

$\dot{\text { پ }}$

เ

జ

능

¿

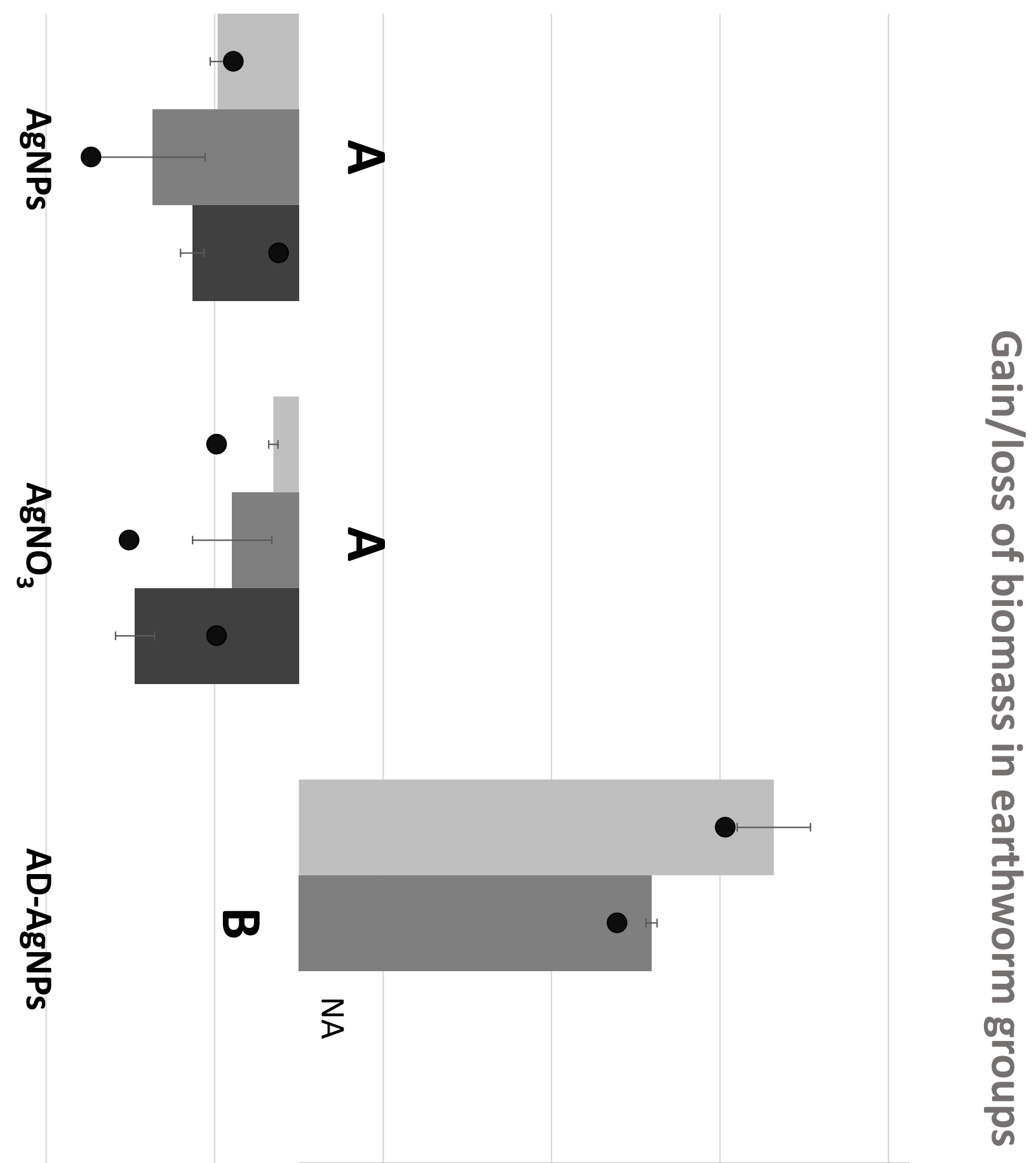

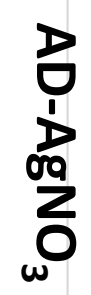

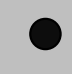

0

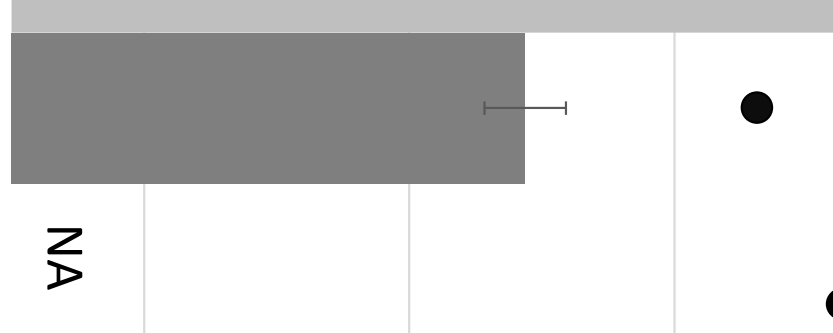

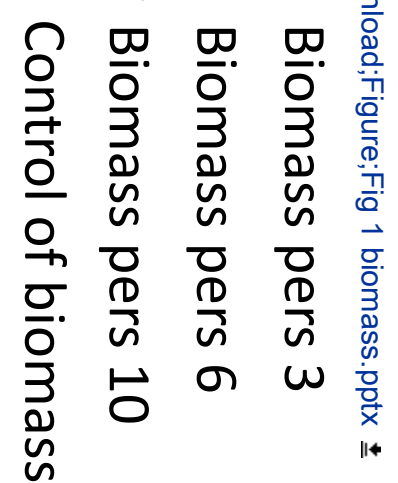




$$
\mu \mathrm{g} \mathrm{C}-\mathrm{CO}_{2} \cdot \mathrm{h}^{-1} \cdot \mathrm{g} \text { dry soil }{ }^{-1}
$$

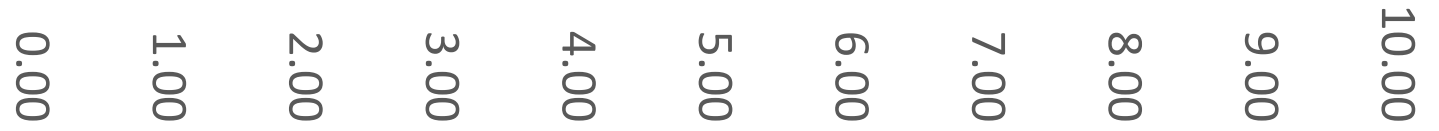

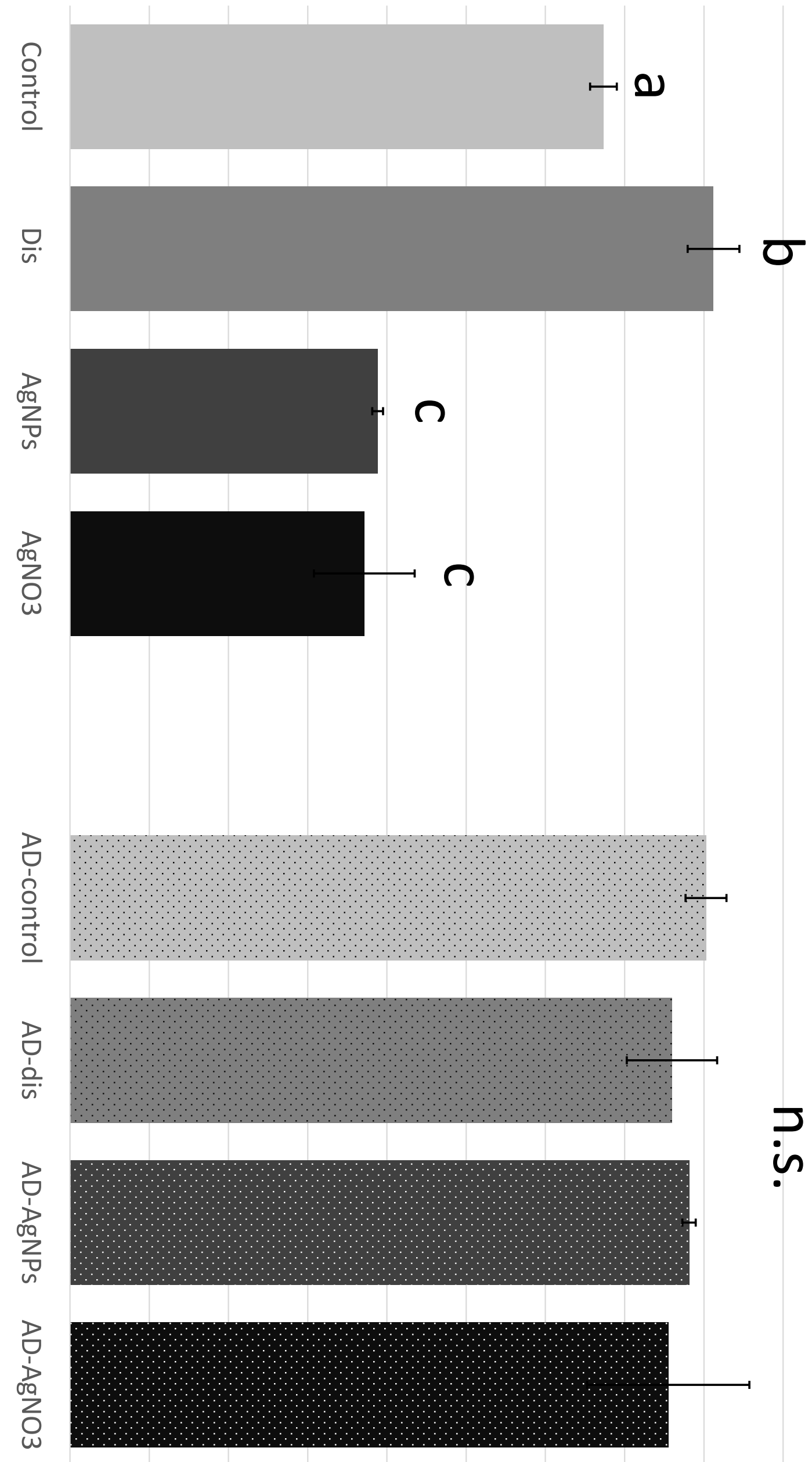

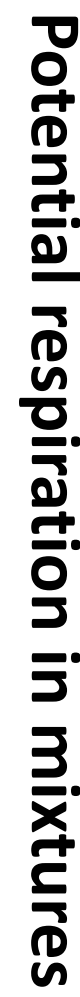



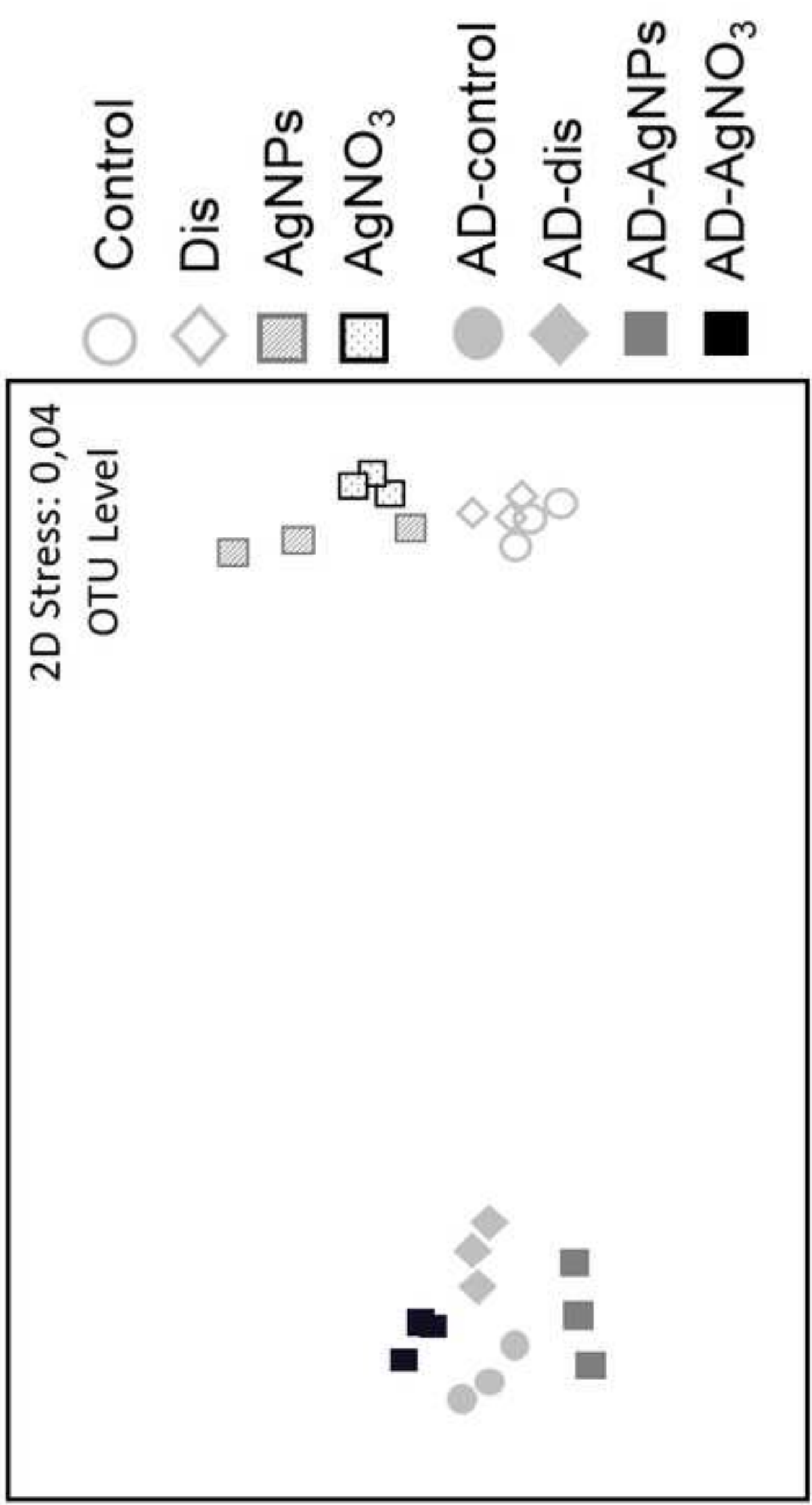

$m$
$\stackrel{0}{\frac{1}{5}}$
믄 

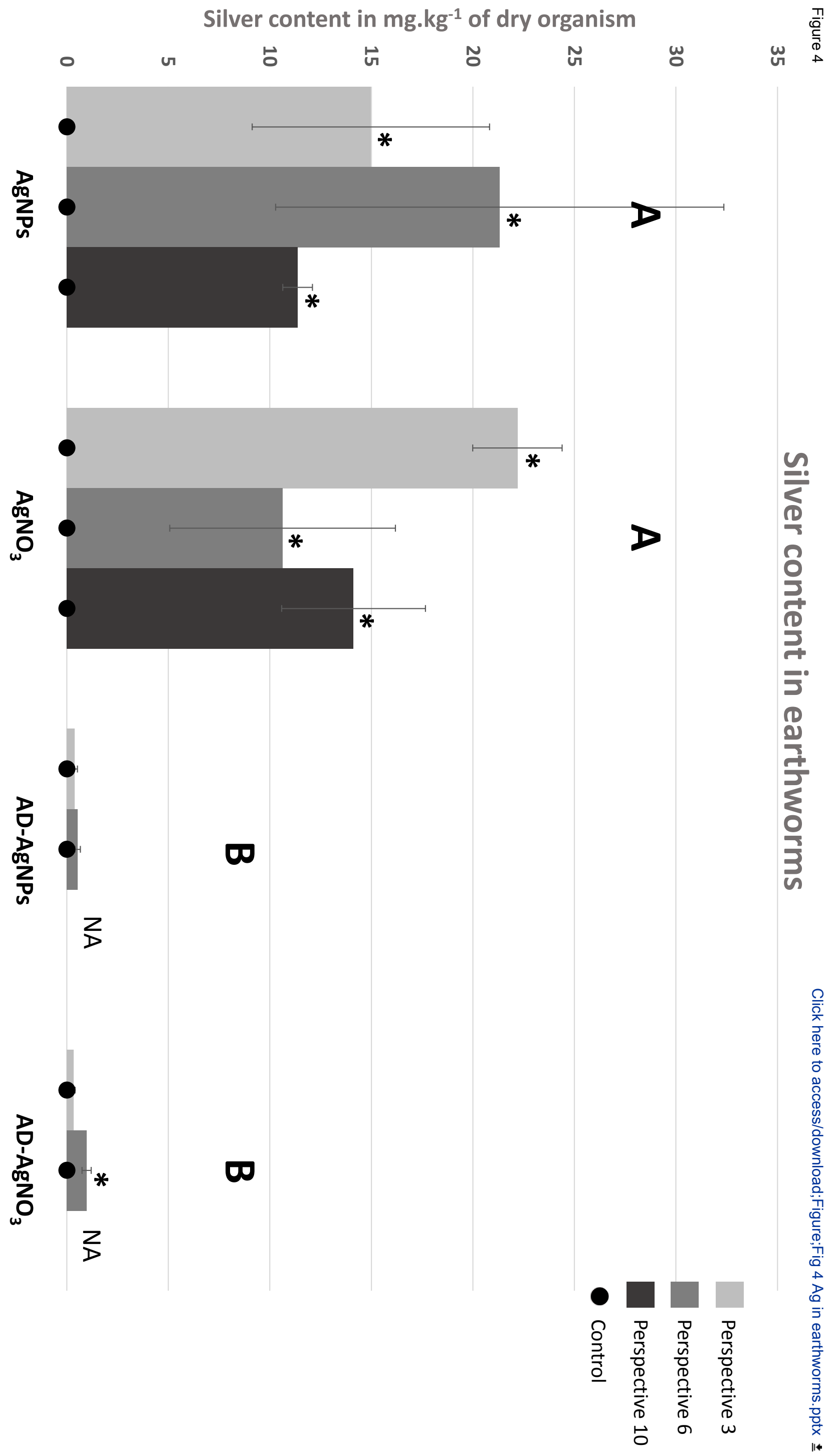


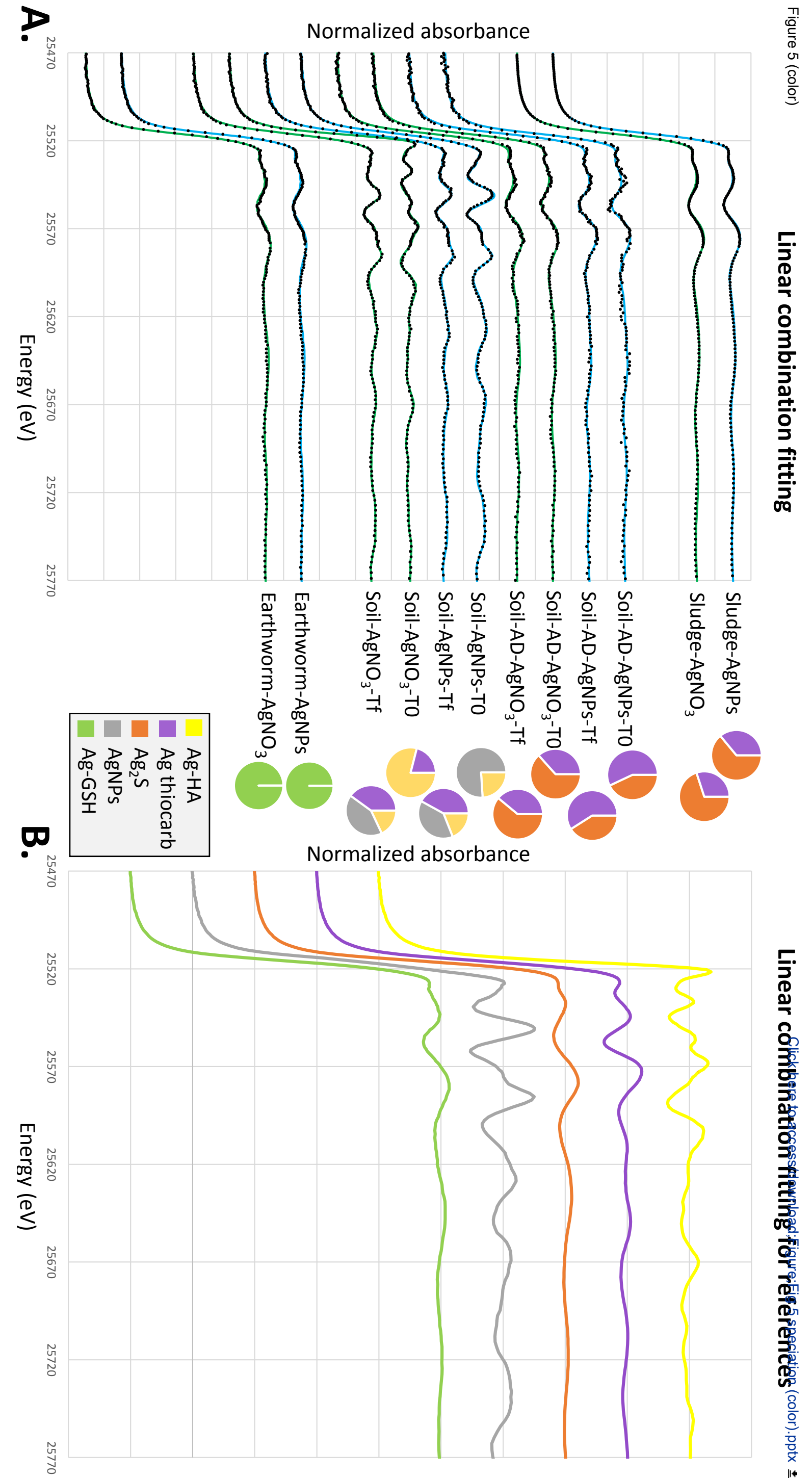




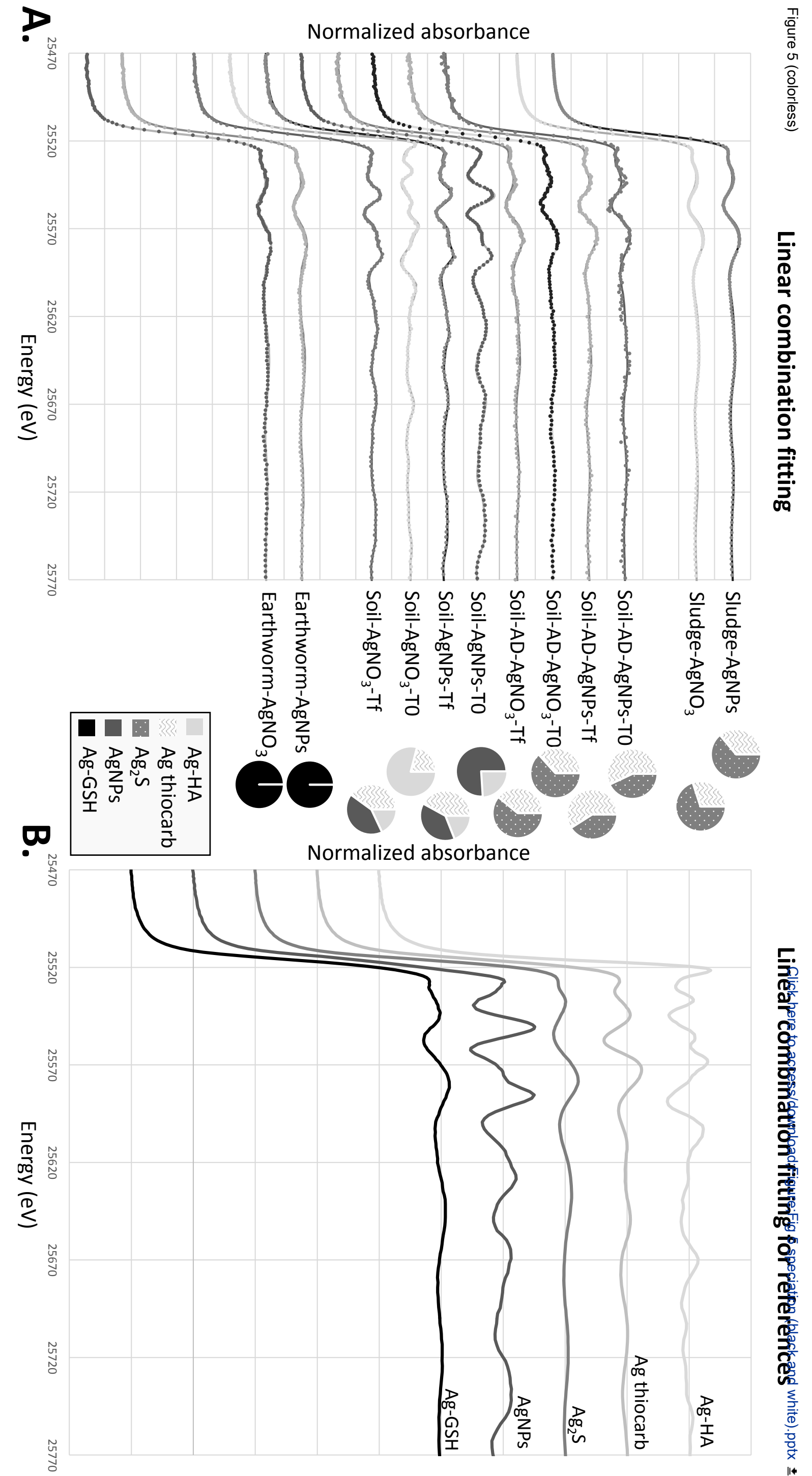


Table 1: Mean percentage of survival in the microcosms. Standard deviations are indicated.

\begin{tabular}{|c|r|r|r|}
\hline & $\begin{array}{l}\text { Survival \% in } \\
\text { Perspective 3 }\end{array}$ & $\begin{array}{c}\text { Survival \% in } \\
\text { Perspective 6 }\end{array}$ & \multicolumn{1}{c|}{$\begin{array}{c}\text { Survival \% in } \\
\text { Perspective 10 }\end{array}$} \\
\hline Control & $100.0 \pm 0.0$ & $97.2 \pm 4.8$ & $100.0 \pm 0.0$ \\
\hline Dis & $100.0 \pm 0.0$ & $100.0 \pm 0.0$ & $97.2 \pm 4.8$ \\
\hline AgNPs & $100.0 \pm 0.0$ & $100.0 \pm 0.0$ & $91.7 \pm 14.4$ \\
\hline $\mathrm{AgNO}_{3}$ & $100.0 \pm 0.0$ & $100.0 \pm 0.0$ & $0.0 \pm 0.0$ \\
\hline $\mathrm{AD}-$ control & $100.0 \pm 0.0$ & $100.0 \pm 0.0$ & $0.0 \pm 0.0$ \\
\hline $\mathrm{AD}-$ dis & $100.0 \pm 0.0$ & $100.0 \pm 0.0$ & $0.0 \pm 0.0$ \\
\hline $\mathrm{AD}-\mathrm{AgNPs}$ & $100.0 \pm 0.0$ & $95.8 \pm 5.9$ & $0.0 \pm 0.0$ \\
\hline $\mathrm{AD}-\mathrm{AgNO} 3$ & $100.0 \pm 0.0$ & $100.0 \pm 0.0$ & 0.0 \\
\hline
\end{tabular}


Table 2: Number of cocoons and juveniles in the microcosms. Standard deviations are indicated. Empty cells in the table corresponds to data no available because of the high mortality in theses conditions.

\begin{tabular}{|l|c|c|c|c|c|c|}
\hline & \multicolumn{3}{|c|}{ Cocoons } & \multicolumn{3}{c|}{ Juveniles } \\
\hline & Perspective 3 & Perspective 6 & Perspective 10 & Perspective 3 & Perspective 6 & Perspective 10 \\
\hline Control & $0 \pm 0$ & $0 \pm 0$ & $0 \pm 0$ & $0 \pm 0$ & 0 & $0 \pm 0$ \\
\hline Dis & $0 \pm 0$ & $0 \pm 0$ & $0 \pm 0$ & $0 \pm 0$ & 0 & $0 \pm 0$ \\
\hline AgNPs & $0 \pm 0$ & $1 \pm 1$ & $0 \pm 0$ & $0 \pm 0$ & $2 \pm 2$ & $0 \pm 0$ \\
\hline AgNO $_{3}$ & $0 \pm 0$ & $0 \pm 0$ & $0 \pm 0$ & $0 \pm 0$ & $1 \pm 1$ & $0 \pm 0$ \\
\hline AD-control & $13 \pm 7$ & $3 \pm 1$ & - & $5 \pm 2$ & 0 & - \\
\hline AD-dis & $7 \pm 2$ & $18 \pm 3$ & - & $5 \pm 2$ & 2 & - \\
\hline AD-AgNPs & $6 \pm 2$ & $10 \pm 2$ & - & $3 \pm 2$ & $1 \pm 1$ & - \\
\hline AD-AgNO 3 & $32 \pm 12$ & $15 \pm 9$ & - & $5 \pm 2$ & $3 \pm 1$ & - \\
\hline
\end{tabular}


Table 2: Silver concentration in mixtures $\left(\mathrm{mg} \mathrm{kg}^{-1}\right.$ of dry mixture). Results were obtained by ICP analysis. Standard deviations are indicated. Some standard deviations are missing due to a lack of replicates

\begin{tabular}{|c|r|r|r|}
\hline Condition & Perspective 3 & Perspective 6 & \multicolumn{1}{|c|}{ Perspective 10 } \\
\hline AD-control & $2.00 \pm 0.61$ & $1.71 \pm 0.23$ & $4.57 \pm 0.86$ \\
\hline AD-AgNPs & $9.54 \pm 0.52$ & $15.00 \pm 1.56$ & $23.77 \pm 1.48$ \\
\hline AD-dis & $3.69 \pm 0.80$ & 2.15 & $8.36 \pm 0.24$ \\
\hline $\mathrm{AD}^{-A g N O} 3$ & $11.63 \pm 0.23$ & 12.60 & $27.97 \pm 5.25$ \\
\hline AgNPs & $11.23 \pm 0.84$ & $0.45 \pm 0.41$ & $27.40 \pm 2.55$ \\
\hline Dis & $2.55 \pm 0.35$ & $22.37 \pm 1.76$ & $22.37 \pm 2.20$ \\
\hline AgNO & $13.83 \pm 0.78$ & $0.09 \pm 0.15$ & 0.87 \\
\hline Control & \multicolumn{2}{|r}{} \\
\hline
\end{tabular}


Click here to access/download Supplementary Material Supplementary material - 210720.docx 
Legend for figure 5 in black and white (for print version) :

Figure 5: A. Speciation of silver in sewage sludge, soils and mixtures at the beginning (T0) or end (Tf) of the soil incubations and speciation of silver in earthworms: linear combination fitting of XANES spectra is shown on the left (dotted lines correspond to experimental data, and solid colored lines correspond to the fits). Samples (soils, mixtures, sewage sludge or earthworms) from conditions with $A g N P S$ and $A g N O_{3}$ are presented. B. XANES spectra of Ag references. Ag-HA (in lightest gray) corresponds to Ag complexed with humic acids. AgNPs (in darkest gray) corresponds to the linear combination fitting obtained with a sample of NM300K AgNPS used for the experiment. $\mathrm{Ag}_{2} \mathrm{~S}$ (in dark gray) corresponds to acanthite, a silver sulfide. Ag-thiocarb (in light gray), and Ag-GSH (in black) corresponds to Ag linked to a thiol-containing organic compound. 